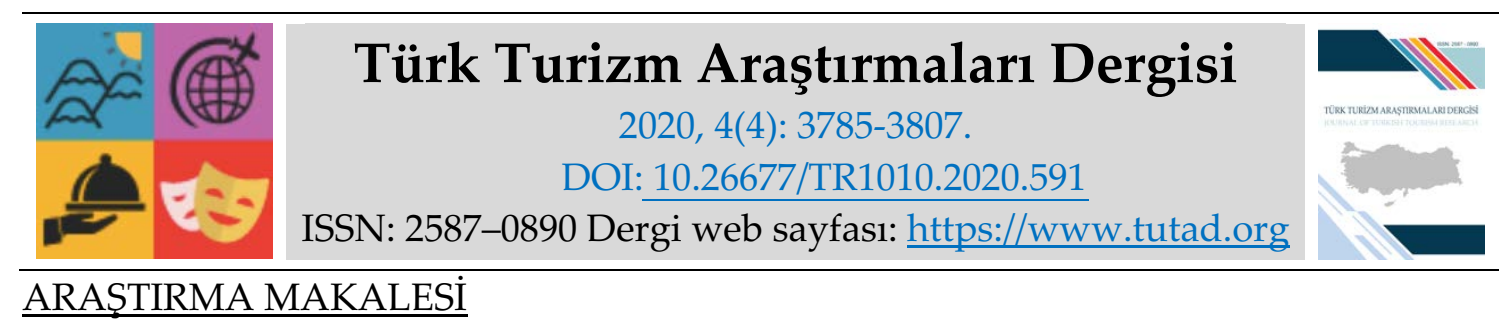

\title{
Seyahat Acenteleri Gözüyle Batı Karadeniz'de Destinasyon Sıralaması: Fuzzy Topsis Yöntemi
}

Dr. Öğr. Üyesi Nalan ALBUZ, Zonguldak Bülent Ecevit Üniversitesi, Karadeniz Ereğli Turizm Fakültesi, Zonguldak, e-posta: nalanalbuz@gmail.com ORCID: https://orcid.org/0000-0003-2111-0842

Dr. Öğr. Üyesi Hasan KÖŞKER, Zonguldak Bülent Ecevit Üniversitesi, Karadeniz Ereğli Turizm Fakültesi, Zonguldak, e-posta: hasankosker@yahoo.com ORCID: https://orcid.org/0000-0003-0662-8301

Arş. Gör. Zeynep KURTULAY, Zonguldak Bülent Ecevit Üniversitesi, Karadeniz Ereğli Turizm Fakültesi, Zonguldak, e-posta: z.kurtulay@beun.edu.tr ORCID: https://orcid.org/0000-0003-1983-362X

Öz

Günümüzde turizm pazarından daha fazla pay almak isteyen ülkeler, bölgeler hatta aynı bölgede bulunan destinasyonlar arasında yoğun bir rekabet yaşanmaktadır. Söz konusu bu rekabet, Batı Karadeniz'de bulunan destinasyonlar arasında da görülmektedir. Bu araştırmanın temel amacı yurtiçinde aktif olarak faaliyet gösteren seyahat acentelerinin gözüyle, bir destinasyonda bulunan kriterlerin önem derecelerini tespit etmek ve Batı Karadeniz Bölgesi'nde yer alan Abant, Akçakoca, Amasra, Safranbolu ve Yedigöller destinasyonlarını, tespit edilen kriterlere göre Fuzzy TOPSIS yöntemiyle sıralamaktır. Çalışmanın bir diğer amacı Batı Karadeniz Bölgesi'nde yer alan turizm destinasyonlarının geliştirilebilmesi için gerekli önerileri sunabilmektir. Çalışmanın son amacı ise bulanık ortamda grup kararı vermeyi kolaylaştıran ve dilsel değişkenleri sayısal olarak ifade etmeye yarayan Fuzzy TOPSIS yönteminin turizm sektöründeki kullanım alanını arttırmaktır. Araştırma verileri, 16-19 Şubat 2019 tarihleri arasında Zonguldak'ın tanıtılması ve turizm potansiyelinin belirlenmesi için düzenlenen tanıtım gezisine katılan 50 kişilik seyahat acentesi yetkililerinden elde edilmiştir. Veriler anket yöntemiyle toplanmış olup, sistematik örneklem seçilebilmesi için her bir katılımcıya bir numara verilmiş ve belirlenen 1/5 örneklem aralığı sonucunda 10 kişilik karar verici grubu oluşturulmuştur. Karar vericilerin, belirlenen kriterler çerçevesinde destinasyonlar için yapmış olduğu değerlendirme ve sıralamalar Fuzzy TOPSIS yöntemi ile analiz edilmiştir. Elde edilen sonuçlara göre sıralama Safranbolu, Amasra, Akçakoca, Abant ve Yedigöller şeklinde oluşmuştur.

Anahtar Kelimeler: Destinasyon Sıralaması, Fuzzy TOPSIS Yöntemi, Batı Karadeniz Bölgesi.

Makale Gönderme Tarihi: 04.07.2020

Makale Kabul Tarihi: 10.10 .2020

\section{Önerilen Atıf:}

Albuz, N., Köşker, H. ve Kurtulay, Z. (2020). Seyahat Acenteleri Gözüyle Batı Karadeniz'de Destinasyon Sıralaması: Fuzzy Topsis Yöntemi, Türk Turizm Araştırmaları Dergisi, 4(4): 3785-3807.

(C) 2020 Türk Turizm Araştırmaları Dergisi. 


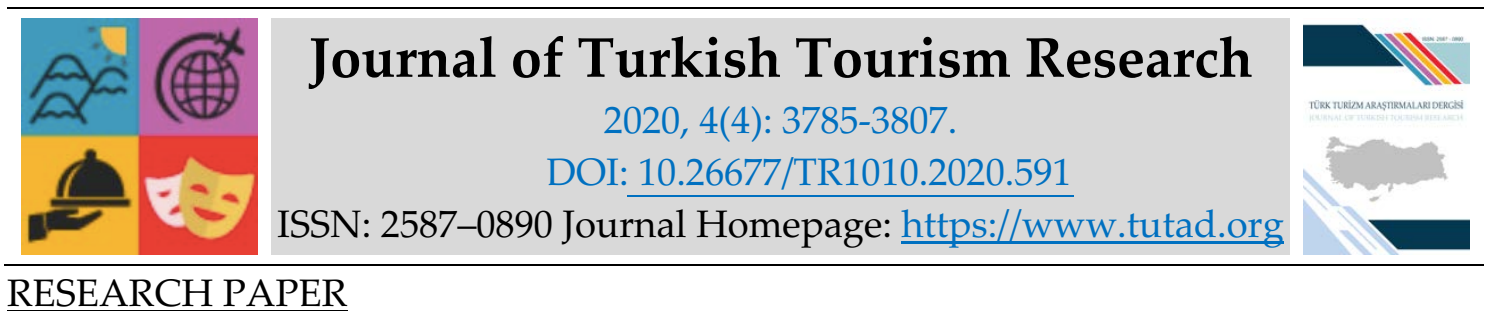

RESEARCH PAPER

\title{
Destination Sorting by The Travel Agencies Perspective in Western Blacksea: Fuzzy Topsis Method
}

Assistant Prof. Dr. Nalan ALBUZ, Zonguldak Bülent Ecevit University, Karadeniz Ereğli Faculty of Tourism, Zonguldak, e-mail: nalanalbuz@gmail.com

ORCID: https://orcid.org/0000-0003-2111-0842

Assistant Prof. Dr. Hasan KÖŞKER, Zonguldak Bülent Ecevit University, Karadeniz Ereğli Faculty of Tourism, Zonguldak, e-mail: hasankosker@yahoo.com

ORCID: https://orcid.org/0000-0003-0662-8301

Research Assistant Zeynep KURTULAY, Zonguldak Bülent Ecevit University, Karadeniz Ereğli Faculty of Tourism, Zonguldak, e-mail: z.kurtulay@beun.edu.tr

ORCID: https://orcid.org/0000-0003-1983-362X

\begin{abstract}
Today, there is an intense competition between countries, regions and even destinations in the same region that want to get more shares from the tourism market. This competition is also seen among the destinations in the Western Blacksea. The main purpose of this research is to determine the importance of the criteria that should be present in a destination through the perspective of travel agencies which actively operating in the inbound tourism in Turkey and to sort the destinations of Western Blacksea region as Abant, Akçakoca, Amasra, Safranbolu and Yedigöller according to the determined criteria by Fuzzy TOPSIS method. Another aim of the study is to present the necessary suggestions for the development of tourism destinations in the West Black Sea region. The last aim of the study is to increase the usage area of the Fuzzy TOPSIS method, which makes it easier to make group decisions in a fuzzy environment and to express the linguistic variables numerically, in the tourism sector. The research data were obtained from the travel agency officials who participated in the promotional trip organized between 16-19th February 2019 and to determine the tourism potential of Zonguldak province. The data were collected by the questionnaire method, each participant was given a number in order to choose a systematic sample and a decision maker of 10 people was formed as a result of the determined $1 / 5$ sample interval. The evaluations and rankings made by the decision makers for the destinations within the framework of the determined criteria were analysed with the Fuzzy TOPSIS method. According to the results obtained, the ranking was formed as Safranbolu, Amasra, Akçakoca, Abant and Yedigöller.
\end{abstract}

Keywords: Destination Sorting, Fuzzy TOPSIS Method, Western Blacksea Region.

Received: 04.07.2020

Accepted: 10.10 .2020

Suggested Citation:

Albuz, N., Köşker, H. and Kurtulay, Z. (2020). Destination Sorting by The Travel Agencies Perspective in Western Blacksea: Fuzzy Topsis Method, Journal of Turkish Tourism Research, 4(4): 3785-3807.

(C) 2020 Türk Turizm Araştırmaları Dergisi. 


\section{Gíriş}

Bir bölgenin, destinasyonun, mal veya hizmetin turistik ürün olarak işlev görebilmesi için öncelikle çekici olması gerekir. Çekicilik bir ülke, bölge, yöre ya da turistik işletmeye talebi yönlendiren turistik akışı sağlayan temel faktörlerdir (Reinius ve Fredman, 2007; Lee vd., 2010; Kim, 2014). Çekicilik, turistin seyahat etmek istediği bir yeri diğer bir yere tercih etmesini etkileyen unsurlar olarak açıklanabilir (Kozak, 2012). Turistik çekicilik yer ve olay çekiciliği şeklinde oluşmaktadır. Yer çekiciliği turisti bir bölgeye çekmek için doğal, tarihi, kültürel, sanatsal, gastronomik unsurlar gibi itici faktörlerdir. Olay çekiciliği ise turisti bir yere gitmek için harekete geçiren festival, şölen, spor müsabakaları, müzik ve eğlence gibi etkinlik ve olaylardır (Olalı, 1990). Yer ve olayla ilgili çekicilik imajları sadece deneyim ve gerçeklerle değil aynı zamanda gezi ve turizmdeki kuvvetli güdüleyicilerle de oluşmaktadır (Rızaoğlu, 2004). Ancak çekicilik tek başına yeterli değildir, çekiciliği tamamlayan bir dizi ürün kombinasyonunun olması gerekmektedir (Olalı ve Timur, 1988; Vila vd., 2010). Zira turistik ürün bir dizi tekil ürün içeren bir ürün kombinasyonundan oluşmaktadır. Turistik ürün kombinasyonunda ulaşılabilirlik, konaklama, yiyecek içecek, eğlence gösterileri, yan ve destek hizmet üniteleri, imaj, fiyat ve diğer kolaylıklar gibi farklı öğe ve bileşenlerin bir bütün olarak birbirini desteklemesi gerekmektedir (Rizaoğlu, 2004).

Bir destinasyonda turizm faaliyetlerinin gelişebilmesi, o destinasyonun sunduğu turistik ürün bileşeninin turistlerin ihtiyaçlarını karşılayabilme oranı ile ilişkilidir. Uluslararası rekabetin arttığ turistik ürün bileşenlerinin olması gerekmektedir (Murfay vd., 2000). Günümüz insanı seyahat olayına katılmadan önce seyahat etmek istediği destinasyonlar hakkında araştırmalar yapmakta, ön bilgiler toplamakta, turistik ürünü tüm bileşenleri ile değerlendirerek bu bilgiler ışığında seyahat kararı almaktadır. Destinasyonun turist çekebilme kabiliyeti, kişiye bireysel faydalar sağlama kabiliyetine bağlıdır (Kim, 2014). Alt yapısı yeterli, turizm yatırımları fazla, olumlu bir imaja sahip, rakiplerinden farklı ve alternatif ürün ve seçenekler sunan destinasyonlar turistler tarafından daha çok tercih edilmektedir (Güzel, 2010).

Günümüzde yalıtılmış veya daha önce yeterince bilinmeyen destinasyonlar turistler tarafından keşfedilmeyi bekleyen yerler haline gelmiştir (Cracolici ve Nijkamp, 2008). Turistik destinasyonların birbirine benzemeyen yapıda olmaları onları özgün kılmaktadır. Ancak turizm sektöründe mevcut destinasyonları geliştirme ya da yeni destinasyonlar oluşturma çabaları birbirine benzeyen destinasyonların ortaya çıkmasına neden olabilmektedir (İçöz, 2013:11). Bu durum makro düzeyde ülkeler, mikro düzeyde destinasyonlar arasında yoğun bir rekabetin yaşanmasına neden olmaktadır (Cucculelli ve Goffi, 2016). Ayrıca turistik destinasyonlar arasında ikame olayı yaygın olduğundan, başarıya ulaşmak için destinasyonların turizm ürününün tüm bileşenlerini etkili ve verimli bir şekilde kullanmaları ve yönetmeleri gerekmektedir (Bornhorst vd., 2010). Kimi destinasyonlar çekim kaynağ1 yeterli ve güçlü olmasına rağmen turistik ürün bileşenlerini etkili olarak kullanamadığından, kaynakları yetersiz olup ancak bu kaynakları turistik ürün bileşenleriyle destekleyerek iyi yöneten destinasyonların gerisinde kalabilmektedir (Ritchie ve Crouch, 2000). Bu açıdan bir destinasyonun, çekiciliklerini turistik ürün bileşenleriyle destekleyerek onları etkili ve verimli olarak yönetebilmesi önem arz etmektedir (Hsu vd., 2009). Dünyada ve Türkiye'de önemli turistik çekicilik unsurlarına sahip olan birçok destinasyon bulunmaktadır. Ancak bu destinasyonlar turistik ürünü oluşturan diğer bileşenlerle yeterince desteklenemediğinden turizm pazarından yeterince pay alamamaktadırlar.

Batı Karadeniz doğal güzellikleri, tarihi ve kültürel dokusuyla Türkiye'nin parlayan önemli bir turizm bölgesidir. Son yıllarda Abant, Akçakoca, Amasra, Safranbolu ve Yedigöller'e yönelik tanıtım ve reklama ağırlık verilmesi, diğer taraftan bu destinasyonlara yönelik özel tur 
programlarının düzenlenmesi bölgeye olan ilgiyi arttırmıştır. Bu çalışmada temel amaç, yurtiçinde aktif olarak faaliyet gösteren seyahat acentelerinin gözüyle, bir destinasyonda bulunan kriterlerin önem derecelerini tespit edebilmek ve Batı Karadeniz Bölgesi'nde yer alan Abant, Akçakoca, Amasra, Safranbolu ve Yedigöller'i tespit edilen kriterlere göre Fuzzy TOPSIS (Tecnique for Order Preference by Smilarity to Ideal Solution) yöntemi ile sıralamaktır. Araştırma kavramsal çerçeve, yöntem, sonuç ve değerlendirmelerle son bulmaktadır.

\section{KAVRAMSAL ÇERÇEVE}

Turistler, içsel motivasyon faktörleriyle seyahat etmeye karar verseler de destinasyon seçim kararlarını etkileyen faktörler içerisinde destinasyonların sahip olduğu çekicilikler ve sundukları turizm ürünleri önemli bir paya sahiptir (Emir vd., 2016:92; Benur ve Bramwell, 2015). Kozak (2019:125), turizm ürününü; fiziksel nesneler, hizmetler, turizm bölgeleri, turizm işletmeleri ve turizm hareketlerine katılanların yararlandıkları veya satın aldıkları her türden etkinlik şeklinde ifade etmektedir. Hacıoğlu (2008:39)'na göre turizm ürünü; 'destinasyonun sahip olduğu tüm doğal, tarihi, kültürel ve turistik kaynakların oluşturduğu turizm ürünü' ile 'turistlerin yer değiştirmelerine ve tatil yapmalarına olanak veren, paket turu oluşturan turistik hizmetlerin tümü' olmak üzere iki şekilde ortaya çıkmaktadır. Genel olarak ele alındığında turizm ürününü oluşturan unsurlar; çekicilik, ulaşılabilirlik, etkinlikler, turizm işletmeleri ve imaj olarak değerlendirilmektedir (Kozak, 2019:127; Meydan Uygur, 2017:205).

Bir destinasyonun turizm ürünü olarak ele alınabilmesi öncelikle birtakım çekiciliklere sahip olmasına bağlıdır. Destinasyon çekiciliği, turistin seyahat etmek istediği bir yeri başka bir yere tercih etmesini etkileyen faktörler olarak da açıklanabilmektedir (Kozak, 2019:127). Bu çekicilikler, İstanbul, Pamukkale, Kapadokya gibi destinasyonla ilgili olabileceği gibi olimpiyatlar, festivaller vb. gibi olay çekiciliği de olabilmektedir. Aynı zamanda doğal unsurlar, sosyo-kültürel unsurlar, ekonomik unsurlar ve psikolojik unsurlar da turizm ürününde çekiliği belirleyen unsurlar olarak bilinmektedir (Meydan Uygur, 2017: 205). Bir destinasyonun ziyaret edilmesinde fiyat da çekicilik unsuru olabilmektedir. Fiyat; ulaşım, gezi, konaklama, yeme-içme, mevcut çekiciliklerden seçilmiş olanlara katılma maliyetlerinin toplamıdır. Destinasyonların, farklı pazarlara yönelik farklı ürünler sunması, fiyatlarda da çeşitlilik oluşmasını sağlamaktadır. Mevsimlere, seyahat mesafesine, ulaştırma araçlarına, turizm işletmelerinin tiplerine, hizmet kalitesine göre değişiklik gösteren fiyatlar (Rızaoğlu, 2004:175), her bütçeden turistin destinasyonu ziyaret etmesini de sağlamaktadır.

Destinasyonun turistik ürün olarak ele alınabilmesi, turistler tarafından ulaşılabilir olmasına da bağlıdır (Sorupia, 2005:1769). Ulaşım; turistlerin sürekli yaşadıkları yerden tatil için seçtikleri destinasyona ulaşmalarında, tatil sonrası geri dönüşlerinde ve destinasyondaki yerel gezilerinde turizmin olmazsa olmazı olarak önemli bir yere sahiptir (Page ve Ge, 2009:371). Aynı zamanda ulaşımın konforu, süresi ve fiyatı; turist deneyimini de etkilemektedir (Volo, 2009; Rodrigue, 2020). Fernández vd. (2020) de çalışmalarında, destinasyonların rekabet gücünü arttırma noktasında, destinasyonların ulaşılabilirliğinin ve destinasyondaki ulaşım alt yapısının önemli bir etken olduğunu belirtmektedir.

Turistik ürünü oluşturan unsurlardan etkinlikler, bazı kaynaklarda çekicilik unsurunun içinde ele alınırken (Rızaoğlu, 2004; Kızılırmak, 2006) bazı kaynaklarda ayrı bir unsur olarak ele alınmaktadır (Kozak, 2019; Meydan Uygur, 2017; Hacığlu, 2008). Ayrı bir unsur olarak da değerlendirilse, çekicilik unsurunun altında da değerlendirilse festivaller, karnavallar, siyasi toplantılar, konserler, ödül törenleri, fuarlar, bilimsel toplantılar, spor organizasyonları gibi etkinlikler turizm ürününü oluşturan diğer unsurlardır. Etkinlikler, çok sayıda turisti destinasyona getirebilen, destinasyonların başarısına, çekiciliğine ve rekabet gücüne önemli 
katkılarda bulunan ve hızla büyüyen profesyonel bir alan olarak değerlendirilmektedir (Getz, 2008).

Turizm, esas itibariyle farklı turizm işletmeleri tarafından üretilen mal ve hizmetleri içeren bir sektördür. Ulaştırma, konaklama ve yeme-içme hizmetinin olmadığ 1 bir turizm hareketinden söz edilememesi, turizm işletmelerinin, turizm ürününün oluşumundaki yerinin daha iyi anlaşılmasını sağlamaktadır (Kozak vd., 2012:43-44). Destinasyonların, farklı amaç ve beklentilerle seyahat eden turistlerin ihtiyaçlarına cevap verebilecek çeşitlilikte, sayıda ve kalitede turizm işletmelerine sahip olması gerekmektedir. Turizm sektörünün temel yapı taşını oluşturan turizm işletmeleri aynı zamanda destinasyonların rekabet gücüne ve olumlu bir imaj geliştirmesine de katkıda bulunmaktadır.

Turistler, geçmiş deneyimleri, çevresindeki insanların açıklamaları, internet ortamında edindikleri bilgiler ve pazarlama kampanyaları aracılığıyla destinasyonlara karşı bir takım beklenti ve algı geliştirirler. Destinasyon imajı, turistlerin sahip oldukları bu algı ve beklentilerin toplamı olarak ifade edilebilmektedir (Buhalis, 2000:101). Konuyla ilgili gerçekleştirilen araştırmalar, destinasyon imajının tatil yeri karar sürecinin en kritik bileşenlerinden biri olduğunu göstermektedir (Buhalis, 2000; Gallarza vd., 2002; Echtner ve Ritchie, 2003; Chen ve Tsai, 2007; Ageeva ve Foroudi, 2019:334). Aynı zamanda destinasyonun turizm pazarında rekabet avantajı elde etmesinde, turist sayısının artmasında, yeni yatırımların gerçekleştirilmesinde ve destinasyonun gelişmesinde de önemli bir faktördür (Ageeva ve Foroudi, 2019:334; Mainolfi ve Marino, 2020:700). Destinasyon pazarlamasının temel amacı potansiyel turistlerin beklentilerini karşılamak için imajlar geliştirmek, imajları sürekli kılmak veya gerektiğinde değiştirmektir (Rızaoğlu, 2004:175). Destinasyon imajı oluşturma, geliştirme ve bu imajı olumlu etkileyecek faktörleri yönetme, turistlerde destinasyona karşı güven oluşturma konusunda kamu kuruluşları başta olmak üzere tüm paydaşlara önemli görevler düşmektedir. Bu bağlamda kendisi de bir turistik ürün olan destinasyonun temel kaynaklarının ve özelliklerinin bilinmesi; destinasyon yöneticilerine yol göstermesi, rekabet avantajı elde edilebilmesi ve uygun stratejilerin geliştirilebilmesi açısından önem arz etmektedir (Islam vd., 2017:10).

Ulucan, Kurtulay ve Kızılırmak (2018); sağlık turizmi destinasyonlarının sahip olduğu kriterlerin önem derecesini tespit etmeye ve sağlık alanında öne çıkan destinasyonların sırasını belirlemeye yönelik çalışmasında Fuzzy TOPSIS yöntemini kullanmışlardır. Bu kapsamda 10 katılımcıya 5 farklı kriter verilmiş ve destinasyonları değerlendirmeleri istenmiştir. Yapılan araştırma sonucunda sağlık turizmi destinasyonları, Afyonkarahisar, Denizli, Yalova, Balıkesir ve Bursa olarak sıralanmıştır.

Kurtulay ve Kızılırmak (2017); karar vericilerin, online rezervasyon kanallarının sahip olduğu kriterlerden hangisini daha önemli bulduklarını tespit etmeye ve online rezervasyon kanallarının öncelik sırasını belirlemeye yönelik çalışmalarında Fuzzy TOPSIS yöntemini kullanmışlardır. Belirlenen dört adet online rezervasyon kanalı bilgi zenginliği, güvenilirlik, dizayn/kullanım kolaylığı, sık güncelleme ve müşteri hizmetleri kriterleri çerçevesinde incelenmiştir. Bilgi zenginliği ve güvenilirlik kriterlerinin daha önemli bulunduğunun tespit edildiği çalışmada, online rezervasyon kanallarının öncelik sıraları da belirlenmiştir.

İlban ve Yıldırım (2017), 'dünyanın en iyi turizm destinasyonlarının turizm faaliyetlerinin çok kriterli karar verme yöntemiyle belirlenmesi' isimli çalışmalarında TOPSIS yönetimini kullanmışlardır. Uluslararası turizm harcamaları, uluslararası turizm gelirleri, uluslararası turist varışları ve uluslararası turist gidişleri olmak üzere toplam 4 kriter temel alınarak 2009 ve 2014 yılları arasında Dünya Turizm Örgütü'nün verilerine göre ilk 10'da yer alan 15 ülkenin performansları değerlendirilmiştir. 4 kriterin temel alındığı araştırmada ülkelerin 2009-2014 periyodundaki sıralamaları yıl bazında verilmiştir. 2014 yılı için sıralama; Amerika, Çin, 
Almanya, Fransa, İngiltere, İspanya, Rusya, İtalya, Kanada, Türkiye, Avusturya, Meksika, Yunanistan, Macaristan ve Polonya şeklinde oluşmuştur.

Hashemabadi ve Razmi (2014), turizmin gelişim göstergelerini kullanarak İran turizm endüstrisinin Ortadoğu'daki konumunu inceledikleri araştırmalarında TOPSIS yöntemini kullanmışlardır. Ortadoğu ülkelerinde turizmin gelişim düzeyini araştırmak amacıyla öncelikle on bir gösterge belirlenmiş ve belirlenen bu göstergeler, İran'ın 1989 ve 2015 yılları arasında hazırladığı birinci, ikinci, üçüncü, dördüncü ve beşinci Ekonomik, Sosyal ve Kültürel Kalkınma Planları temel alınarak incelenmiştir. Araştırmada her bir kalkınma planı doğrultusunda Orta Doğu'da yer alan 19 ülke arasında İran'ın sıralaması verilmiştir.

Moosivand ve Farahani (2013), araştırmalarında TOPSIS ve Analitik Hiyerarşi Süreci (AHP) yöntemlerini bir arada kullanmışlardır. İran'ın İsfahan eyaletindeki şehirler, sahip oldukları turizm altyapı yoğunluğuna göre dokuz faktör temel alınarak TOPSIS yöntemiyle sıralanmıştır. Sıralamada ilk beş şehir sırasıyla Isfahan, Kashan, Shahin Shahr, Ardestan ve Shahreza şeklinde oluşmuştur.

Önder, Yıldırım ve Özdemir (2013), Türkiye'deki turizm destinasyonlarının rekabet gücünü değerlendirmek amacıyla gerçekleştirdikleri araştırmalarında TOPSIS ve Analitik Hiyerarşi Süreci (AHP) yöntemlerini bir arada kullanmışlardır. Çalışma da nicel ve nitel olmak üzere iki ana kriter ile 31 alt kriter temel alınarak 13 turizm destinasyonunun rekabet gücüne göre sıralaması yapılmıştır. İlk 3 destinasyonun sıralaması Alanya, Marmaris ve Bodrum şeklinde oluşmuştur.

Huang ve Peng (2012), 2009 yılında dokuz Asya ülkesinin, turizm endüstrisindeki rekabet gücünü değerlendirmek amacıyla bir araştırma gerçekleştirmişlerdir. Turizm endüstrisindeki rekabet güçlerini belirlemek amaciyla bu dokuz Asya ülkesi 6 ana kriter ve 15 alt kriter temel alınarak TOPSIS yöntemiyle sıralanmıştır. Sıralama rekabet gücü en yüksek olandan en düşük olana doğru şu şekilde oluşmuştur; Çin, Japonya, Hong Kong, Malezya, Tayland, Singapur, Tayvan, Kore ve Filipinler.

\section{YÖNTEM}

Gerçekleştirilen bu çalışmada temel amaç, yurtiçinde aktif olarak faaliyet gösteren seyahat acentalarının gözünden, bir destinasyonda bulunan kriterlerin önem derecelerini tespit etmek ve Batı Karadeniz Bölgesi'nde yer alan turizm destinasyonlarını, tespit edilen kriterlere göre Fuzzy TOPSIS yöntemi ile sıralamaktır. Çalışmanın bir diğer amacı Batı Karadeniz Bölgesi'nde bulunan turizm destinasyonlarının geliştirilebilmesi için öneriler sunmaktır. Çalışmanın son amacı ise karar vericilerin, öznel kriterler nedeniyle birbirinden farklı seçimler yaptığı bulanık ortamlarda karar vermeyi kolaylaştıran ve dilsel değişkenleri sayısal olarak ifade etmeye olanak sağlayan Fuzzy TOPSIS yönteminin turizm sektöründe bilinirliğini arttırmak ve kullanımını yaygınlaştırmaktır.

$\mathrm{Bu}$ araştırmanın örneklemini Batı Karadeniz Bölgesi'nde yer alan ve seyahat acentalarının turlarında yoğun olarak yer verdiği Abant, Akçakoca, Amasra, Safranbolu ve Yedigöller oluşturmaktadır. Değerlendirme kriterlerini belirlemek amacıyla, turistik çekicilik unsurları ile ilgili çalışmalar incelenmiş (Tatar, Atak ve Tunaseli, 2017:978; Klenosky, 2002:387; Uysal, Li, ve Sirakaya-Turk, 2008:415) ve 10 adet kriter tespit edilmiştir. Bu kriterler ise doğal çekicilik unsurlarının olması, tarihi ve kültürel çekicilik unsurlarmm olması, fiyatların uygun olması, ulaşım imkanlarının kolaylığı, konaklama işletmelerinin varlığı, yiyecek-içecek işletmelerinin varlı̆̆l, diğer turizm işletmelerinin varlı̆̆l, ziyaret etmeye değer bir destinasyon olması, seyahat acentelerinin tur programlarında yer alması ve destinasyona özgü etkinliklerin yapılması olarak belirlenmiş̧ir. 
Bu çalışmada yer alan karar vericileri, 16-19 Şubat 2019 tarihleri arasında Zonguldak'ın tanıtılması ve turizm potansiyelinin belirlenmesi için düzenlenen tanıtım gezisine katılan seyahat acentası yetkilileri oluşturmaktadır. Veriler anket yoluyla toplanmış olup, 50 anketten sistematik örneklem yöntemi ile 10 katılımcı seçilmiştir. Sistematik örneklem yönteminde, evreni oluşturan birimler numaralandırılmakta ve belirlenen aralıklarla atlanarak örneklem seçilmektedir (Kılıç, 2013:45). Sistematik örneklemin, rastgele yönteme kıyasla daha kolay uygulanması nedeniyle çalışmada sistematik örneklem tercih edilmiştir. Bu amaçla, evreni oluşturan her bir katılımcıya bir numara verilmiştir. 10 kişilik örneklemin seçilebilmesi için, örneklem büyüklüğü (10) evren büyüklüğüne (50) bölünmüş ve örneklem aralığ $1 / 5$ olarak tespit edilmiştir. Böylelikle evrende yer alan her beşinci kişi seçilerek örneklem oluşturulmuştur.

\section{Fuzzy TOPSIS Yöntemi}

Bireyler günlük yaşantıları içerisinde karar verirken, iyi-kötü, güzel-çirkin vb. pek çok öznel ifade kullanmaktadır. Bu nedenle kesin ayrımların ve ikili karşılaştırmaların gerçekleştirilemediği bir ortam meydana gelmektedir. Bulanık mantık olarak da ifade edilebilen bu durumda evet-hayır, doğru-yanlış gibi seçeneklerin arasında kalan birçok seçenek bulunmaktadır. Bu bulanık seçenekler ise bulanık (fuzzy) kümeleri oluşturur (Göksu ve Güngör, 2008:3). İlk kez 1965 yılında Prof. Dr. Lotfi A. Zadeh tarafından ortaya atılan bulanık mantık, 1981 yılında ise Hwang ve Yoon tarafından ortaya atılan Fuzzy TOPSIS yöntemi çözümlenmeye çalışılmıştır. Fuzzy TOPSIS yöntemi, grup kararı verilirken ideal çözüme en uygun uzaklı̆̆ı kullanarak kriterleri sıralamaya çalışan bir çözümdür (Wang ve Elhag, 2006:310). Diğer bir ifade ile Fuzzy TOPSIS yöntemi, reel sayılar yerine bulanık sayıları kullanarak, verilen alternatiflerin özniteliklerinin önemini belirlemekte ve buna göre alternatifleri sıralamaktadır (Chen ve Tsao, 2008:1411). Yirminci yüzyılın sonlarına doğru yaygınlık kazanan Fuzzy TOPSIS yöntemi hakkında, derecelendirme aşamasında kullanılan bulanık sayılar arasındaki sıralamanın farklı şekillerde ele alınması nedeniyle çeşitli eksiklikler öne sürülmüştür (Chu, 2002:688). Ancak bu durum Chen-Tung Chen (2000) tarafından yayınlanan makale ile giderilmiştir.

Fuzzy TOPSIS yönteminin uygulanabilmesi için; öncelikle karar vericiler, karar kriterleri ve alternatiflerin belirlenmesi gerekmektedir. İlk aşamada karar vericiler, kendilerine sunulan karar kriterlerinin önem düzeyini öznel olarak değerlendirmektedir. Daha sonra da verilen alternatifleri, karar kriterlerini kullanarak sıralamaktadır (Ecer, 2006:78). Bu aşamada ise bulanık ortamda yeterince tanımlanmamış ifadeleri nicel olarak tanımlamaya yarayan dilsel değişkenler kullanılmaktadır (Chen vd., 2006:291). Dilsel değişkenlerin kullanılması sonucunda elde edilen veriler, bulanık sayılar kullanılarak üyelik fonksiyonlarına dönüştürülerek sayısal olarak ifade edilebilir.

Fuzzy TOPSIS algoritmasında yer alan problemlerin daha iyi sonuçlar verebilmesi ve karar verebilmenin sağlıklı olabilmesi için bulanık sayılar kullanılmaktadır. Bulanık sayılar, reel sayıların bir uzantısıdır. Bulanık sayılar olası her bir değerin 0 ile 1 arasında yer aldığı ve kendi ağırlığına sahip olduğu olası değerler kümesini ifade etmektedir (Anand ve Bharatraj, 2017:80).

İşlem kolaylığı sağlaması nedeniyle en çok tercih edilen bulanık sayılar, üçgensel bulanık sayılardır (Chen, 2000:3). $\tilde{A}=a_{1}, a_{2}, a_{3}$ olmak üzere; aşağıdaki koşulları sağlayan bir üçgensel bulanık sayının üyelik fonksiyonu ve şekil üzerinde gösterimi şöyledir (Gani, 2012:527):
i. $a_{1}{ }^{\prime}$ den $a_{2}{ }^{\prime}$ ye artan fonksiyon,
ii. $\quad a_{2}{ }^{\prime} \operatorname{den} a_{3}{ }^{\prime}$ e azalan fonksiyon,
iii. $\quad a_{1}<a_{2}<a_{3}$ 


$$
\begin{aligned}
& \mu_{\tilde{\mathrm{A}}}(x)=f(x) \\
& =\left\{\begin{array}{c}
\frac{x-a_{1}}{a_{2}-a_{1}}, a_{1} \leq x \leq a_{2} \\
\frac{a_{3}-x}{a_{3}-a_{2}}, a_{2} \leq x \leq a_{3} \\
0, x>a_{3}
\end{array}\right.
\end{aligned}
$$

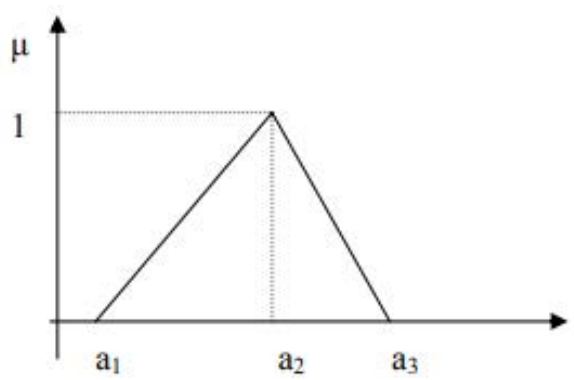

Şekil 1: Üçgensel bulanık sayılar

Verilen iki üçgensel bulanık sayı arasındaki uzaklık, Vertex yöntemi ile hesaplanır. Buna göre, $\widetilde{m}=\left(m_{1}, m_{2}, m_{3}\right)$ ve $\tilde{n}=\left(n_{1}, n_{2}, n_{3}\right)$ olarak ifade edilen farklı iki üçgensel bulanık sayı arasındaki uzaklık Vertex formülü ile hesaplanacak olursa (Chen, 2000:3);

$d(\widetilde{m}, \tilde{n})=\sqrt{\frac{1}{2}\left[\left(m_{1}-n_{1}\right)^{2}+\left(m_{2}-n_{2}\right)^{2}+\left(m_{3}-n_{3}\right)^{2}\right]}$

Karar vericilerin, kendilerine yöneltilen kriterleri ve alternatifleri değerlendirilebilmeleri için dilsel değişkenlere ihtiyaç duymaktadır. Dilsel değişkenler sayesinde, karar vericiler kendilerine verilen kriterleri önem düzeni belirlemekte ve buna göre bir sıralama yapmaktadır. Daha sonra karar vericiler, önem dereceleri belirlenen kriterlere sahip olma durumlarına göre alternatifleri siralamaktadır.

Fuzzy TOPSIS yönteminde kullanılan dilsel değişkenler ve bu değişkenler Tablo 1 ve Tablo 2' de sunulmuştur (Chen, 2000:5).

Tablo 1. Kullanılan Dilsel Değişkenlerin Her Kriter İçin Önem Ağırlıkları

\begin{tabular}{ccccc}
\hline ÇD & Çok Düşük & 0 & 0 & 0.1 \\
\hline $\mathbf{D}$ & Düşük & 0 & 0.1 & 0.3 \\
\hline $\mathbf{O D}$ & Orta Düşük & 0.1 & 0.3 & 0.5 \\
\hline $\mathbf{O}$ & Orta & 0.3 & 0.5 & 0.7 \\
\hline OY & Orta Yüksek & 0.5 & 0.7 & 0.9 \\
\hline $\mathbf{Y}$ & Yüksek & 0.7 & 0.9 & 1.0 \\
\hline ÇY & Çok Yüksek & 0.9 & 1.0 & 1.0 \\
\hline
\end{tabular}


Tablo 2. Değerlendirme Kriterleri İçin Kullanılan Dilsel Değişkenler

\begin{tabular}{ccccc}
\hline ÇK & Çok Kötü & 0 & 0 & 1 \\
\hline $\mathbf{K}$ & Kötü & 0 & 1 & 3 \\
\hline $\mathbf{O K}$ & Orta Kötü & 1 & 3 & 5 \\
\hline $\mathbf{E}$ & Epeyce & 3 & 5 & 7 \\
\hline $\mathbf{B \dot { \mathbf { I } }}$ & Biraz İyi & 5 & 7 & 9 \\
\hline$\dot{\mathbf{I}}$ & İyi & 7 & 9 & 10 \\
\hline Çi் & Çok İyi & 9 & 10 & 10 \\
\hline
\end{tabular}

Araştırmada yer alan $K$ adet karar vericiden oluşturulan bir grubun içerisinde $\widetilde{w}_{j}^{K} \mathrm{~K}^{\prime}$ ıncı karar vericinin önem ağırlığını, $\tilde{x}_{i j}^{K}$ ise söz konusu karar vericinin, kriter önem derecesini ifade etmek üzere aşağıda verilen şekilde hesaplanmaktadır;

$\widetilde{w}_{j}=\frac{1}{K}\left[\widetilde{w}_{j}^{1}(+) \widetilde{w}_{j}^{2}(+) \widetilde{w}_{j}^{3}(+) \ldots \ldots \ldots \widetilde{w}_{j}^{K}\right]$ ve

$\tilde{x}_{i j}=\frac{1}{K}\left[\tilde{x}_{i j}^{1}(+) \tilde{x}_{i j}^{2}(+) \tilde{x}_{i j}^{3}(+) \ldots \ldots \ldots \ldots \tilde{x}_{i j}^{1}\right]$ olur

n kriterden oluşan ve m seçeneği bulunan bir Fuzzy matrisi şu şekilde oluşturulmaktadır;

$C_{1}, C_{2}, C_{3}, \ldots \ldots . . . C_{n}$

$\widetilde{D}=\underset{A_{2}}{A_{1}}\left[\begin{array}{ccccc}x_{11} & x_{12} & x_{13} & \cdots & x_{1 n} \\ x_{12} & x_{22} & x_{23} & \cdots & x_{2 n} \\ A_{m} & \vdots & \vdots & \cdots & \vdots \\ x_{m 1} & x_{m 2} & x_{m 3} & \cdots & x_{m n}\end{array}\right], \widetilde{W}=\left[w_{1}, w_{2}, w_{3} \ldots \ldots w_{n}\right]$ olarak ifade edilir.

Yukarıda verilmiş olan ifadelerdeki $\widetilde{D}$ Fuzzy karar matrisini, $\tilde{x}_{i j}\left(\forall_{i, j}\right)$ ve $\widetilde{w}_{j}(j=1,2,3, \ldots . n)$ katılımcıların sıralama yaparken kullandığı dilsel değişkenleri ve $\widetilde{W}$ ise Fuzzy TOPSIS ağrılıklar matrisini temsil etmektedir. Verilen bu dilsel değişkenler, $\tilde{x}_{i j}=\left(a_{i j}, b_{i j}, c_{i j}\right)$ ve $\widetilde{w}_{j}=$ $\left(w_{j 1}, w_{j 2}, w_{j 3}\right)$ olarak üçgensel bulanık sayılar olarak ifade edilebilmektedir.

$X$ 'in en az bir elemanı için " 1 " tam üyelik değerini alan $\tilde{A}$ bulanık kümesi, normal küme olarak ifade edilmektedir. Normalize edilmiş bir Fuzzy karar matrisi $R$ ile ifade edilir ve

$R=\left[\gamma_{i j}\right]_{\mathrm{m} \times n}$ şeklinde gösterilmektedir.

$B$ fayda kriteri kümesini ifade etmek üzere;

$\gamma_{i j}=\left(\frac{a_{i j}}{c_{j}^{*}}, \frac{b_{i j}}{c_{j}^{*}}, \frac{c_{i j}}{c_{j}^{*}}\right), j \in B ; \quad c_{l}^{*} \max _{i} c_{i j}, \quad j \in B$ şeklinde hesaplanır

Yukarıda gösterilen normalleşme metodu sayesinde, üçgensel bulanık sayıları normal hale getirilir ve bu sayıların $[0,1]$ arasında yer alması sağlanır.

Karar kriterlerinin birbirinden farklı önem ağırlıkları olmaktadır. Bu ağırlıklar göz önünde bulundurularak oluşturulacak ağırlıklı normalize Fuzzy karar matrisi şu şekilde ifade edilir

$V=\left[v_{i j}\right]_{m \times n} i=1,2,3 \ldots . . m ; j=1,2,3 \ldots . . n$ ve bu denklemde

$v_{i j}=\gamma_{i j}(.) w_{j} \quad$ formülü kullanılarak hesaplanır. 
Ağırlıklı normalize edilmiş Fuzzy karar matrisine göre, $\forall_{i j}$ için $v_{i j}$ elemanları, normalize hale getirilmiş pozitif üçgelsel Fuzzy sayılardır. Bu sayılar [0,1] aralığında bulunmaktadır. Fuzzy pozitif ideal çözüm $\left(A^{*}\right)$ ve Fuzzy negatif ideal çözüm $\left(A^{-}\right)$olarak ifade edilirse;

$A^{*}=\left(v_{1}^{*}, v_{2}^{*}, v_{3}^{*} \cdots v_{n}^{*}\right)$ ve $A^{-}=\left(v_{1}^{-}, v_{2}^{-}, v_{3}^{-} \cdots v_{n}^{-}\right)$olarak tanimlanmaktadır. $v_{j}^{*}=(1,1,1)$ ve $v_{j}^{-}=$ $(0,0,0)$ olarak kabul edilmektedir. Araştırmaya konu olan her bir alternatifin Fuzzy pozitif ve Fuzzy negatif ideal çözüm kümesine olan uzaklıkları;

$d_{i}^{*} \sum_{j=1}^{n} d\left(v_{i j}, v_{j}^{*}\right), i=1,2,3 \ldots . . m$

$d_{i}^{-} \sum_{j=1}^{n} d\left(v_{i j}, v_{j}^{-}\right), i=1,2,3 \ldots . m$

Yukarıda verilmiş olan formüllerdeki $d(i)$ iki bulanık sayı arasındaki uzaklığı temsil etmektedir. Araştırmaya konu olan her bir alternatifin sıralanabilmesi için bir yakınlık katsayısına ihtiyaç duyulmaktadır. Yakınlık kat sayısı ise;

$C C_{i}=\frac{d_{i}^{-}}{d_{i}^{*}+d_{i}^{-}}$formülü yardımıyla hesaplanmaktadır.

Bütün hesaplamalar sonucunda elde edilen $C C_{i}$ yakınlık katsayısının mümkün olduğunca 1'e yakın olması beklenir. Bir alternatifin yakınlık katsayısı 1'e ne kadar yakınsa, söz konusu alternatifin seçilme olasılığının daha yüksek olduğu anlamına gelmektedir.

\section{Uygulama}

Araştırmaya katılan her bir seyahat acentası yetkilisine bir numara verilmiş, katılımcılar arasından sistematik örneklem yoluyla ve $1 / 5$ örneklem aralığında her beşinci kişi araştırmaya karar verici olarak dahil edilmiştir. Dahil edilen karar vericiler ise $\mathrm{KV}_{1}, \mathrm{KV}_{2}, \mathrm{KV}_{3}, \mathrm{KV}_{4}, \mathrm{KV}_{5}, \mathrm{KV}_{6}$, $\mathrm{KV}_{7}, \mathrm{KV}_{8}, \mathrm{KV}_{9}$ ve $\mathrm{KV}_{10}$ olarak kodlanmıştır. Çalışmanın devamında karar vericiler yerine $\mathrm{KV}$ ifadesi kullanılmıştır.

İkinci adım olarak KV'lere sunulan değerlendirme kriterleri de $C_{1}$ (Doğal çekicilik unsurlarının olması), $C_{2}$ (Tarihi ve kültürel çekicilik unsurlarının olması), $C_{3}$ (Fiyatların uygun olması), $C_{4}$ (Ulaşım imkanlarının kolaylığı), $C_{5}$ (Konaklama işletmelerinin varlığı), $C_{6}$ (Yiyecek-içecek işletmelerinin varlığı), $C_{7}$ (Diğer turizm işletmelerinin varlığı), $C_{8}$ (Ziyaret etmeye değer bir destinasyon olmasi), $C_{9}$ (Seyahat acentalarının tur programlarında yer almasi) ve $C_{10}$ (Destinasyona özgü etkinliklerin yapılması) olarak kodlanmıştır. Daha sonra KV'den kendilerine sunulan kriterleri, Tablo 1'de verilen dilsel değişkenleri kullanarak değerlendirmesi istenmiştir. Elde edilen sonuçlar Tablo 3'te sunulmuştur.

Sonraki adım olarak KV'lere sunulan ve Batı Karadeniz Bölgesi'nde yer alan destinasyon alternatifleri de $\mathrm{A}_{1}$ (Safranbolu), A2 (Akçakoca), A (Amasra), $\mathrm{A}_{4}$ (Yedigöller) ve $\mathrm{A}_{5}$ (Abant) olarak kodlanmıştır. Daha sonra KV'lerden kendilerine sunulan destinasyon alternatiflerini ve sahip olduğu kriterleri Tablo 2'de verilen dilsel değişkenleri kullanarak değerlendirmesi istenmiştir. Elde edilen sonuçlar Tablo 4'te sunulmuştur. 
Tablo 3. Değerlendirme Kriterlerinin Karar Vericiler Tarafından Değerlendirilmesi

\begin{tabular}{|c|c|c|c|c|c|c|c|c|c|c|}
\hline & $\mathrm{KV}_{1}$ & $\mathrm{KV}_{2}$ & $\mathrm{KV}_{3}$ & $\mathrm{KV}_{4}$ & $\mathrm{KV}_{5}$ & $\mathrm{KV}_{6}$ & $\mathrm{KV}_{7}$ & $\mathrm{KV}_{8}$ & $\mathrm{KV}_{9}$ & $K V_{10}$ \\
\hline $\mathrm{C}_{1}$ & ÇY & $\mathrm{O}$ & $\mathrm{Y}$ & $\mathrm{O}$ & OD & OY & ÇY & ÇY & ÇY & OD \\
\hline $\mathrm{C}_{2}$ & ÇY & OY & $\mathrm{Y}$ & $\mathrm{O}$ & OD & $\mathrm{O}$ & ÇY & ÇY & ÇY & $\mathrm{O}$ \\
\hline $\mathrm{C}_{3}$ & $\mathrm{Y}$ & $\mathrm{D}$ & $\mathrm{O}$ & OD & $\mathrm{O}$ & $\mathrm{O}$ & OY & ÇY & ÇY & OY \\
\hline $\mathrm{C}_{4}$ & ÇY & $\mathrm{D}$ & ÇY & OY & OD & OY & OY & OD & ÇY & $\mathrm{Y}$ \\
\hline$C_{5}$ & ÇY & $\mathrm{D}$ & $\mathrm{Y}$ & ÇD & $\mathrm{D}$ & OD & OY & ÇD & $\mathrm{D}$ & OY \\
\hline $\mathrm{C}_{6}$ & $\mathrm{Y}$ & $\mathrm{D}$ & ÇY & $\mathrm{D}$ & $\mathrm{D}$ & $\mathrm{O}$ & $\mathrm{Y}$ & ÇD & ÇY & $\mathrm{O}$ \\
\hline $\mathrm{C}_{7}$ & Y & OD & ÇY & $\mathrm{D}$ & $\mathrm{D}$ & OD & Y & OD & $\mathrm{O}$ & $\mathrm{O}$ \\
\hline $\mathrm{C}_{8}$ & OY & $\mathrm{D}$ & OY & OD & OD & OY & ÇY & $\mathrm{Y}$ & ÇY & ÇY \\
\hline $\mathrm{C}_{9}$ & $\mathrm{Y}$ & OD & ÇY & OD & $\mathrm{O}$ & OY & ÇY & ÇY & ÇY & ÇY \\
\hline $\mathrm{C}_{10}$ & $\mathrm{O}$ & ÇD & ÇY & $\mathrm{D}$ & $\mathrm{O}$ & OY & ÇY & $\mathrm{Y}$ & $\mathrm{D}$ & ÇY \\
\hline
\end{tabular}

Tablo 4. Destinasyon Alternatiflerinin Karar Vericiler Tarafından Değerlendirilmesi

\begin{tabular}{|c|c|c|c|c|c|c|c|c|c|c|c|}
\hline Kriter & Alt. & $\mathrm{KV}_{1}$ & $\mathrm{KV}_{2}$ & $\mathrm{KV}_{3}$ & $\mathrm{KV}_{4}$ & $\mathrm{KV}_{5}$ & $\mathrm{KV}_{6}$ & $\mathrm{KV}_{7}$ & $\mathrm{KV}_{8}$ & $\mathrm{KV}_{9}$ & $\mathrm{KV}_{10}$ \\
\hline \multirow{5}{*}{ 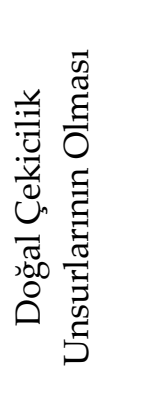 } & $\mathrm{A}_{1}$ & Çİ & OK & Çİ & E & Bİ & $\dot{I}$ & $\dot{I}$ & Çİ & Çİ & Bं \\
\hline & $\mathrm{A}_{2}$ & Çİ & $\mathrm{K}$ & Çİ & OK & Bİ & $\dot{I}$ & Çİ & Bİ & Çİ & OK \\
\hline & $\mathrm{A}_{3}$ & Çİ & Bİ & Çİ & Bİ & İ & Bİ & Çİ & İ & Ç̇̇ & Bİ \\
\hline & $\mathrm{A}_{4}$ & Çİ & çİ & Çİ & Bİ & Çİ & Bİ & Çİ & Çİ & Çi் & Çİ \\
\hline & $\mathrm{A}_{5}$ & Çİ & Çİ & Çİ & İ & İ & İ & Çİ & İ & Ç̇̇ & Çİ \\
\hline \multirow{5}{*}{ 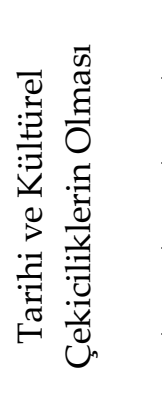 } & $\mathrm{A}_{1}$ & Çİ & E & Çİ & OK & Bİ & İ & Çİ & Çİ & Çİ & İ \\
\hline & $\mathrm{A}_{2}$ & Çİ & OK & Çİ & OK & Bİ & Bİ & E & İ & Ç̇̇ & E \\
\hline & $\mathrm{A}_{3}$ & Çİ & $\dot{\mathrm{I}}$ & Bİ & Bİ & $\mathrm{E}$ & Bİ & Çİ & Bİ & Çİ & $\dot{\mathrm{I}}$ \\
\hline & $\mathrm{A}_{4}$ & $\mathrm{~K}$ & $\dot{I}$ & $\mathrm{~K}$ & $\mathrm{~K}$ & OK & E & ÇK & $\mathrm{E}$ & Çİ & Bं \\
\hline & $\mathrm{A}_{5}$ & E & $\mathrm{K}$ & ÇK & K & OK & Bİ & $\mathrm{K}$ & $\mathrm{E}$ & Çİ & $\mathrm{E}$ \\
\hline \multirow{3}{*}{ 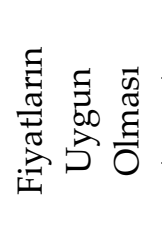 } & $\mathrm{A}_{1}$ & $\dot{I}$ & ÇK & E & E & $\mathrm{K}$ & E & OK & Bİ & Bİ & $\mathrm{E}$ \\
\hline & $\mathrm{A}_{2}$ & Çİ & E & E & Bİ & $\mathrm{E}$ & E & OK & OK & Bİ & $\mathrm{K}$ \\
\hline & $\mathrm{A}_{3}$ & çİ & Bं் & E & E & OK & E & Çİ & E & çi் & E \\
\hline
\end{tabular}




\begin{tabular}{|c|c|c|c|c|c|c|c|c|c|c|c|}
\hline & $\mathrm{A}_{4}$ & OK & İ & Bİ & Bİ & OK & $\mathrm{E}$ & $\mathrm{K}$ & İ & $\dot{\mathrm{I}}$ & OK \\
\hline & $\mathrm{A}_{5}$ & $\mathrm{~K}$ & $\mathrm{~K}$ & $\mathrm{E}$ & $\mathrm{K}$ & $\mathrm{K}$ & OK & $\mathrm{K}$ & $\mathrm{K}$ & $\mathrm{E}$ & OK \\
\hline \multirow{5}{*}{ 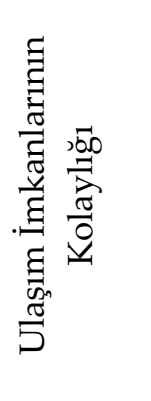 } & $\mathrm{A}_{1}$ & Çİ & $\mathrm{K}$ & Çİ & $\mathrm{E}$ & Bİ & E & OK & E & Bİ & $\dot{\mathrm{I}}$ \\
\hline & $\mathrm{A}_{2}$ & İ & Bİ & Çİ & Bİ & OK & E & OK & OK & Çİ & Bİ \\
\hline & $\mathrm{A}_{3}$ & $\dot{\mathrm{I}}$ & E & OK & Çİ & OK & OK & $\mathrm{E}$ & E & Bİ & Bİ \\
\hline & $\mathrm{A}_{4}$ & ÇK & İ & Çİ & Bİ & $\mathrm{K}$ & OK & $\mathrm{K}$ & E & İ & İ \\
\hline & $\mathrm{A}_{5}$ & Çİ & Çİ & Çİ & E & $\dot{\mathrm{I}}$ & Bİ & Bİ & E & Çİ & $\mathrm{K}$ \\
\hline \multirow{5}{*}{ 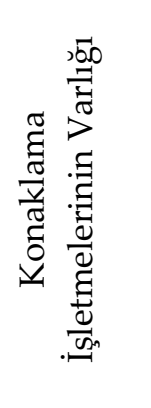 } & $\mathrm{A}_{1}$ & İ & E & $\dot{\mathrm{I}}$ & İ & Bİ & Bİ & İ & $\dot{\mathrm{I}}$ & İ & Bİ \\
\hline & $\mathrm{A}_{2}$ & $\dot{\mathrm{I}}$ & OK & $\dot{I}$ & Bİ & $\dot{\mathrm{I}}$ & E & Bİ & OK & İ & OK \\
\hline & $\mathrm{A}_{3}$ & İ & İ & $\dot{I}$ & Çİ & OK & Bİ & Çİ & E & Bİ & Bİ \\
\hline & $\mathrm{A}_{4}$ & ÇK & İ & E & ÇK & $\mathrm{K}$ & OK & $\mathrm{K}$ & $\mathrm{E}$ & Çİ & $\mathrm{E}$ \\
\hline & $\mathrm{A}_{5}$ & $\dot{\mathrm{I}}$ & $\dot{I}$ & ÇK & $\dot{\mathrm{I}}$ & $\dot{I}$ & Bİ & Bİ & E & Çİ & $\dot{\mathrm{I}}$ \\
\hline \multirow{5}{*}{ 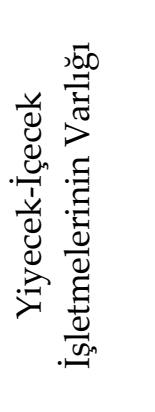 } & $\mathrm{A}_{1}$ & İ & $\dot{\mathrm{I}}$ & $\dot{I}$ & İ & $\dot{\mathrm{I}}$ & Bİ & $\dot{I}$ & Bİ & Çİ & Bİ \\
\hline & $\mathrm{A}_{2}$ & Çİ & E & Çİ & İ & Bİ & Bİ & İ & OK & Çİ & $\mathrm{E}$ \\
\hline & $\mathrm{A}_{3}$ & Bİ & E & $\dot{I}$ & $\dot{I}$ & Bİ & E & E & Bİ & $\mathrm{E}$ & $\mathrm{E}$ \\
\hline & $\mathrm{A}_{4}$ & ÇK & $\dot{\mathrm{I}}$ & Çİ & ÇK & $\mathrm{K}$ & OK & $\mathrm{K}$ & E & Bİ & $\mathrm{E}$ \\
\hline & $\mathrm{A}_{5}$ & BI் & Bİ & Çİ & $\dot{\mathrm{I}}$ & $\dot{\mathrm{I}}$ & E & Bİ & $\mathrm{E}$ & Çİ & $\mathrm{E}$ \\
\hline \multirow{5}{*}{ 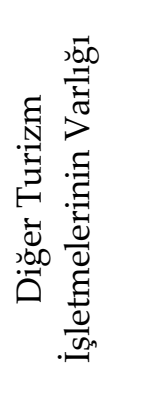 } & $\mathrm{A}_{1}$ & Çİ & E & Çİ & $\dot{\mathrm{I}}$ & İ & İ & İ & E & OK & Bİ \\
\hline & $\mathrm{A}_{2}$ & $\dot{\mathrm{I}}$ & OK & BI் & OK & OK & Bİ & İ & OK & OK & $\mathrm{E}$ \\
\hline & $\mathrm{A}_{3}$ & İ & Bİ & BI் & Çİ & OK & $\dot{I}$ & Çİ & OK & E & $\mathrm{E}$ \\
\hline & $\mathrm{A}_{4}$ & K & İ & ÇK & ÇK & $\mathrm{K}$ & $\dot{I}$ & $\mathrm{~K}$ & İ & Bİ & $\mathrm{E}$ \\
\hline & $\mathrm{A}_{5}$ & E & Bİ & OK & Bİ & OK & E & OK & E & Bİ & $\mathrm{E}$ \\
\hline \multirow{4}{*}{ 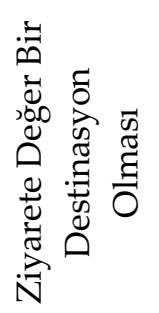 } & $\mathrm{A}_{1}$ & İ & Çİ & Çİ & $\dot{I}$ & Bİ & $\dot{I}$ & Çİ & Çİ & OK & Çİ \\
\hline & $\mathrm{A}_{2}$ & $\dot{I}$ & E & $\dot{I}$ & E & E & İ & Bİ & İ & Bİ & $\dot{\mathrm{I}}$ \\
\hline & $\mathrm{A}_{3}$ & Bİ & $\dot{\mathrm{I}}$ & İ & Çİ & $\dot{I}$ & Çİ & Çİ & Bİ & $\mathrm{E}$ & Çİ \\
\hline & $\mathrm{A}_{4}$ & OK & Çİ & Çİ & OK & Çİ & $\dot{I}$ & Çİ & Çİ & Çİ & Çİ \\
\hline
\end{tabular}




\begin{tabular}{|c|c|c|c|c|c|c|c|c|c|c|c|}
\hline & $\mathrm{A}_{5}$ & $\dot{\mathrm{I}}$ & Bİ & çİ & OK & Çİ & İ & Çİ & İ & Bİ & Çì \\
\hline \multirow{5}{*}{ 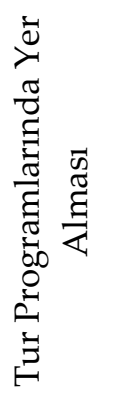 } & $\mathrm{A}_{1}$ & İ & $\mathrm{K}$ & İ & İ & Çİ & Çİ & Çİ & Çİ & İ & Çì \\
\hline & $\mathrm{A}_{2}$ & $\dot{\mathrm{I}}$ & Bİ & E & $\dot{\mathrm{I}}$ & Bİ & Çİ & Çİ & Bİ & $\dot{\mathrm{I}}$ & $\dot{\mathrm{I}}$ \\
\hline & $\mathrm{A}_{3}$ & İ & Bİ & $\dot{\mathrm{I}}$ & E & Çİ & Çİ & Çİ & OK & E & Çì \\
\hline & $\mathrm{A}_{4}$ & Bİ & İ & OK & Çİ & Çİ & Çİ & Çİ & İ & $\dot{I}$ & Çi \\
\hline & $\mathrm{A}_{5}$ & $\dot{\mathrm{I}}$ & İ & OK & $\dot{\mathrm{I}}$ & Çİ & Çİ & Çİ & Çİ & Bİ & Çì \\
\hline \multirow{5}{*}{ 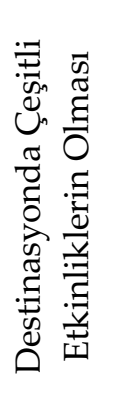 } & $\mathrm{A}_{1}$ & Bİ & İ & Çİ & Bİ & OK & Çİ & OK & Bİ & $\mathrm{K}$ & Çì \\
\hline & $\mathrm{A}_{2}$ & $\dot{\mathrm{I}}$ & OK & İ & E & Bİ & Çİ & $\dot{\mathrm{I}}$ & E & $\mathrm{K}$ & $\dot{\mathrm{I}}$ \\
\hline & $\mathrm{A}_{3}$ & Bİ & İ & E & Çİ & Bİ & Çİ & E & OK & E & Çì \\
\hline & $\mathrm{A}_{4}$ & Bİ & Çİ & ÇK & OK & OK & Çİ & $\mathrm{K}$ & E & Bİ & Çì \\
\hline & $\mathrm{A}_{5}$ & Bİ & $\dot{\mathrm{I}}$ & ÇK & Bİ & $\dot{\mathrm{I}}$ & Çİ & OK & $\dot{\mathrm{I}}$ & Bİ & Çi \\
\hline
\end{tabular}

Tablo 2 ve Tablo 3 'te yer alan dilsel değişkenler yardımıyla Fuzzy karar matrisinin oluşturulabilmesi ve bu matris içerisindeki her bir kriterin Fuzzy ağırlığının hesaplanabilmesi için Tablo 1 ve Tablo 2 kullanılmış ve dilsel değişkenler pozitif üçgensel bulanık sayılara dönüştürülmüştür. Elde edilen sonuçlar Tablo 5 ve Tablo $6^{\prime}$ da sunulmuştur.

Tablo 5. Değerlendirme Kriterlerinin Önem Ağırlıklarının Pozitif Üçgensel Bulanık Sayılara Dönüştürülmesi

\begin{tabular}{|c|c|c|c|c|c|c|c|c|c|c|}
\hline & $\mathrm{KV}_{1}$ & $\mathrm{KV}_{2}$ & $\mathrm{KV}_{3}$ & $\mathrm{KV}_{4}$ & $\mathrm{KV}_{5}$ & $\mathrm{KV}_{6}$ & $\mathrm{KV}_{7}$ & $\mathrm{KV}_{8}$ & $\mathrm{KV}_{9}$ & $\mathrm{KV}_{10}$ \\
\hline \multirow{3}{*}{$\mathrm{C}_{1}$} & 0.9 & 0.3 & 0.7 & 0.3 & 0.1 & 0.5 & 0.9 & 0.9 & 0.9 & 0.1 \\
\hline & 1.0 & 0.5 & 0.9 & 0.5 & 0.3 & 0.7 & 1.0 & 1.0 & 1.0 & 0.3 \\
\hline & 1.0 & 0.7 & 1.0 & 0.7 & 0.5 & 0.9 & 1.0 & 1.0 & 1.0 & 0.5 \\
\hline \multirow{3}{*}{$\mathrm{C}_{2}$} & 0.1 & 0.5 & 0.7 & 0.3 & 0.1 & 0.3 & 0.9 & 0.9 & 0.9 & 0.3 \\
\hline & 0.3 & 0.7 & 0.9 & 0.5 & 0.3 & 0.5 & 1.0 & 1.0 & 1.0 & 0.5 \\
\hline & 0.5 & 0.9 & 1.0 & 0.7 & 0.5 & 0.7 & 1.0 & 1.0 & 1.0 & 0.7 \\
\hline \multirow{3}{*}{$\mathrm{C}_{3}$} & 0.7 & 0.0 & 0.3 & 0.1 & 0.3 & 0.3 & 0.5 & 0.9 & 0.9 & 0.5 \\
\hline & 0.9 & 0.1 & 0.5 & 0.3 & 0.5 & 0.5 & 0.7 & 1.0 & 1.0 & 0.7 \\
\hline & 1.0 & 0.3 & 0.7 & 0.5 & 0.7 & 0.7 & 0.9 & 1.0 & 1.0 & 0.9 \\
\hline \multirow{3}{*}{$\mathrm{C}_{4}$} & 0.9 & 0.0 & 0.9 & 0.5 & 0.1 & 0.5 & 0.5 & 0.1 & 0.9 & 0.7 \\
\hline & 1.0 & 0.1 & 1.0 & 0.7 & 0.3 & 0.7 & 0.7 & 0.3 & 1.0 & 0.9 \\
\hline & 1.0 & 0.3 & 1.0 & 0.9 & 0.5 & 0.9 & 0.9 & 0.5 & 1.0 & 1.0 \\
\hline
\end{tabular}




\begin{tabular}{|c|c|c|c|c|c|c|c|c|c|c|}
\hline & 0.9 & 0.0 & 0.7 & 0.0 & 0.0 & 0.1 & 0.5 & 0.0 & 0.0 & 0.5 \\
\hline \multirow[t]{3}{*}{$\mathrm{C}_{5}$} & 1.0 & 0.1 & 0.9 & 0.0 & 0.1 & 0.3 & 0.7 & 0.0 & 0.1 & 0.7 \\
\hline & 1.0 & 0.3 & 1.0 & 0.1 & 0.3 & 0.5 & 0.9 & 0.1 & 0.3 & 0.9 \\
\hline & 0.7 & 0.0 & 0.9 & 0.0 & 0.0 & 0.3 & 0.7 & 0.0 & 0.9 & 0.3 \\
\hline \multirow[t]{3}{*}{$\mathrm{C}_{6}$} & 0.9 & 0.1 & 1.0 & 0.1 & 0.1 & 0.5 & 0.9 & 0.0 & 1.0 & 0.5 \\
\hline & 1.0 & 0.3 & 1.0 & 0.3 & 0.3 & 0.7 & 1.0 & 0.1 & 1.0 & 0.7 \\
\hline & 0.7 & 0.1 & 0.9 & 0.0 & 0.0 & 0.1 & 0.7 & 0.1 & 0.3 & 0.3 \\
\hline \multirow[t]{3}{*}{$\mathrm{C}_{7}$} & 0.9 & 0.3 & 1.0 & 0.1 & 0.1 & 0.3 & 0.9 & 0.3 & 0.5 & 0.5 \\
\hline & 1.0 & 0.5 & 1.0 & 0.3 & 0.3 & 0.5 & 1.0 & 0.5 & 0.7 & 0.7 \\
\hline & 0.5 & 0.0 & 0.5 & 0.1 & 0.1 & 0.5 & 0.9 & 0.7 & 0.9 & 0.9 \\
\hline \multirow[t]{3}{*}{$\mathrm{C}_{8}$} & 0.7 & 0.1 & 0.7 & 0.3 & 0.3 & 0.7 & 1.0 & 0.9 & 1.0 & 1.0 \\
\hline & 0.9 & 0.3 & 0.9 & 0.5 & 0.5 & 0.9 & 1.0 & 1.0 & 1.0 & 1.0 \\
\hline & 0.7 & 0.1 & 0.9 & 0.1 & 0.3 & 0.5 & 0.9 & 0.9 & 0.9 & 0.9 \\
\hline \multirow[t]{3}{*}{$\mathrm{C}_{9}$} & 0.9 & 0.3 & 1.0 & 0.3 & 0.5 & 0.7 & 1.0 & 1.0 & 1.0 & 1.0 \\
\hline & 1.0 & 0.5 & 1.0 & 0.5 & 0.7 & 0.9 & 1.0 & 1.0 & 1.0 & 1.0 \\
\hline & 0.3 & 0.0 & 0.9 & 0.0 & 0.3 & 0.5 & 0.9 & 0.7 & 0.0 & 0.9 \\
\hline \multirow[t]{2}{*}{$\mathrm{C}_{10}$} & 0.5 & 0.0 & 1.0 & 0.1 & 0.5 & 0.7 & 1.0 & 0.9 & 0.1 & 1.0 \\
\hline & 0.7 & 0.1 & 1.0 & 0.3 & 0.7 & 0.9 & 1.0 & 1.0 & 0.3 & 1.0 \\
\hline
\end{tabular}

Tablo 6. Destinasyon Alternatifi Değerlendirme Sonuçlarının Pozitif Üçgensel Bulanık Sayılara Dönüştürülmesi

\begin{tabular}{|c|c|c|c|c|c|c|c|c|c|c|c|}
\hline Kriter & Alt. & $\mathrm{KV}_{1}$ & $\mathrm{KV}_{2}$ & $\mathrm{KV}_{3}$ & $\mathrm{KV}_{4}$ & $\mathrm{KV}_{5}$ & $\mathrm{KV}_{6}$ & $\mathrm{KV}_{7}$ & $\mathrm{KV}_{8}$ & $\mathrm{KV}_{9}$ & $\mathrm{KV}_{10}$ \\
\hline \multirow{5}{*}{ 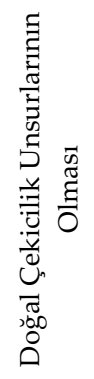 } & $\mathbf{A}_{1}$ & $9,10,10$ & $1,3,5$ & $9,10,10$ & $3,5,7$ & $5,7,9$ & $7,9,10$ & $7,9,10$ & $9,10,10$ & $9,10,10$ & $5,7,9$ \\
\hline & $\mathbf{A}_{2}$ & $9,10,10$ & $0,1,3$ & $9,10,10$ & $1,3,5$ & $5,7,9$ & $7,9,10$ & $9,10,10$ & $5,7,9$ & $9,10,10$ & $1,3,5$ \\
\hline & $\mathbf{A}_{3}$ & $9,10,10$ & $5,7,9$ & $9,10,10$ & $5,7,9$ & $7,9,10$ & $5,7,9$ & $9,10,10$ & $7,9,10$ & $9,10,10$ & $5,7,9$ \\
\hline & $\mathbf{A}_{4}$ & $9,10,10$ & $9,10,10$ & $9,10,10$ & $5,7,9$ & $9,10,10$ & $5,7,9$ & $9,10,10$ & $9,10,10$ & $9,10,10$ & $9,10,10$ \\
\hline & $\mathbf{A}_{5}$ & $9,10,10$ & $9,10,10$ & $9,10,10$ & $7,9,10$ & $7,9,10$ & $7,9,10$ & $9,10,10$ & $7,9,10$ & $9,10,10$ & $9,10,10$ \\
\hline \multirow{5}{*}{ 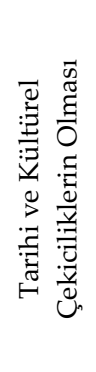 } & $\mathbf{A}_{1}$ & $9,10,10$ & $3,5,7$ & $9,10,10$ & $1,3,5$ & $5,7,9$ & $7,9,10$ & $9,10,10$ & $9,10,10$ & $9,10,10$ & $7,9,10$ \\
\hline & $\mathbf{A}_{2}$ & $9,10,10$ & $1,3,5$ & $9,10,10$ & $1,3,5$ & $5,7,9$ & $5,7,9$ & $3,5,7$ & $7,9,10$ & $9,10,10$ & $3,5,7$ \\
\hline & $\mathbf{A}_{3}$ & $9,10,10$ & $7,9,10$ & $5,7,9$ & $5,7,9$ & $3,5,7$ & $5,7,9$ & $9,10,10$ & $5,7,9$ & $9,10,10$ & $7,9,10$ \\
\hline & $\mathbf{A}_{4}$ & $0,1,3$ & $7,9,10$ & $0,1,3$ & $0,1,3$ & $1,3,5$ & $3,5,7$ & $0,0,1$ & $3,5,7$ & $9,10,10$ & $5,7,9$ \\
\hline & $\mathbf{A}_{5}$ & $3,5,7$ & $0,1,3$ & $0,0,1$ & $0,1,3$ & $1,3,5$ & $5,7,9$ & $0,1,3$ & $3,5,7$ & $9,10,10$ & $3,5,7$ \\
\hline
\end{tabular}




\begin{tabular}{|c|c|c|c|c|c|c|c|c|c|c|c|}
\hline \multirow{5}{*}{ 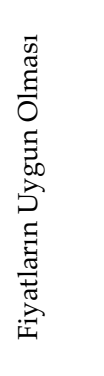 } & $A_{1}$ & $7,9,10$ & $0,0,1$ & $3,5,7$ & $3,5,7$ & $0,1,3$ & $3,5,7$ & $1,3,5$ & $5,7,9$ & $5,7,9$ & $3,5,7$ \\
\hline & $\mathrm{A}_{2}$ & $9,10,10$ & $3,5,7$ & $3,5,7$ & $5,7,9$ & $3,5,7$ & $3,5,7$ & $1,3,5$ & $1,3,5$ & $5,7,9$ & $0,1,3$ \\
\hline & $\mathrm{A}_{3}$ & $9,10,10$ & $5,7,9$ & $3,5,7$ & $3,5,7$ & $1,3,5$ & $3,5,7$ & $9,10,10$ & $3,5,7$ & $9,10,10$ & $3,5,7$ \\
\hline & $\mathbf{A}_{4}$ & $1,3,5$ & $7,9,10$ & $5,7,9$ & $5,7,9$ & $1,3,5$ & $3,5,7$ & $0,1,3$ & $7,9,10$ & $7,9,10$ & $1,3,5$ \\
\hline & $\mathrm{A}_{5}$ & $0,1,3$ & $0,1,3$ & $3,5,7$ & $0,1,3$ & $0,1,3$ & $1,3,5$ & $0,1,3$ & $0,1,3$ & $3,5,7$ & $1,3,5$ \\
\hline \multirow{5}{*}{ 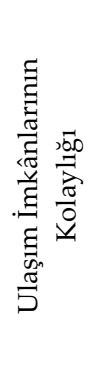 } & $\mathbf{A}_{1}$ & $9,10,10$ & $0,1,3$ & $9,10,10$ & $3,5,7$ & $5,7,9$ & $3,5,7$ & $1,3,5$ & $3,5,7$ & $5,7,9$ & $7,9,10$ \\
\hline & $\mathrm{A}_{2}$ & $7,9,10$ & $5,7,9$ & $9,10,10$ & $5,7,9$ & $1,3,5$ & $3,5,7$ & $1,3,5$ & $1,3,5$ & $9,10,10$ & $5,7,9$ \\
\hline & $\mathrm{A}_{3}$ & $7,9,10$ & $3,5,7$ & $1,3,5$ & $9,10,10$ & $1,3,5$ & $1,3,5$ & $3,5,7$ & $3,5,7$ & $5,7,9$ & $5,7,9$ \\
\hline & $\mathbf{A}_{4}$ & $0,0,1$ & $7,9,10$ & $9,10,10$ & $5,7,9$ & $0,1,3$ & $1,3,5$ & $0,1,3$ & $3,5,7$ & $7,9,10$ & $7,9,10$ \\
\hline & $\mathrm{A}_{5}$ & $9,10,10$ & $9,10,10$ & $9,10,10$ & $3,5,7$ & $7,9,10$ & $5,7,9$ & $5,7,9$ & $3,5,7$ & $9,10,10$ & $0,1,3$ \\
\hline \multirow{5}{*}{ 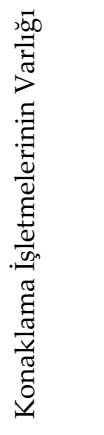 } & $\mathbf{A}_{1}$ & $7,9,10$ & $3,5,7$ & $7,9,10$ & $7,9,10$ & $5,7,9$ & $5,7,9$ & $7,9,10$ & $7,9,10$ & $7,9,10$ & $5,7,9$ \\
\hline & $\mathrm{A}_{2}$ & $7,9,10$ & $1,3,5$ & $7,9,10$ & $5,7,9$ & $7,9,10$ & $3,5,7$ & $5,7,9$ & $1,3,5$ & $7,9,10$ & $1,3,5$ \\
\hline & $\mathrm{A}_{3}$ & $7,9,10$ & $7,9,10$ & $7,9,10$ & $9,10,10$ & $1,3,5$ & $5,7,9$ & $9,10,10$ & $3,5,7$ & $5,7,9$ & $5,7,9$ \\
\hline & $\mathbf{A}_{4}$ & $0,0,1$ & $7,9,10$ & $3,5,7$ & $0,0,1$ & $0,1,3$ & $1,3,5$ & $0,1,3$ & $3,5,7$ & $9,10,10$ & $3,5,7$ \\
\hline & $\mathrm{A}_{5}$ & $7,9,10$ & $7,9,10$ & $0,0,1$ & $7,9,10$ & $7,9,10$ & $5,7,9$ & $5,7,9$ & $3,5,7$ & $9,10,10$ & $7,9,10$ \\
\hline \multirow{5}{*}{ 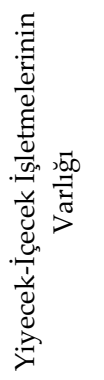 } & $\mathbf{A}_{1}$ & $7,9,10$ & $7,9,10$ & $7,9,10$ & $7,9,10$ & $7,9,10$ & $5,7,9$ & $7,9,10$ & $5,7,9$ & $9,10,10$ & $5,7,9$ \\
\hline & $\mathbf{A}_{2}$ & $9,10,10$ & $3,5,7$ & $9,10,10$ & $7,9,10$ & $5,7,9$ & $5,7,9$ & $7,9,10$ & $1,3,5$ & $9,10,10$ & $3,5,7$ \\
\hline & $\mathrm{A}_{3}$ & $5,7,9$ & $3,5,7$ & $7,9,10$ & $7,9,10$ & $5,7,9$ & $3,5,7$ & $3,5,7$ & $5,7,9$ & $3,5,7$ & $3,5,7$ \\
\hline & $\mathbf{A}_{4}$ & $0,0,1$ & $7,9,10$ & $9,10,10$ & $0,0,1$ & $0,1,3$ & $1,3,5$ & $0,1,3$ & $3,5,7$ & $5,7,9$ & $3,5,7$ \\
\hline & $\mathrm{A}_{5}$ & $5,7,9$ & $5,7,9$ & $9,10,10$ & $7,9,10$ & $7,9,10$ & $3,5,7$ & $5,7,9$ & $3,5,7$ & $9,10,10$ & $3,5,7$ \\
\hline \multirow{5}{*}{ 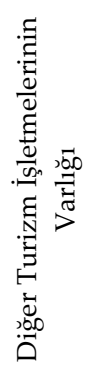 } & $\mathbf{A}_{1}$ & $9,10,10$ & $3,5,7$ & $9,10,10$ & $7,9,10$ & $7,9,10$ & $7,9,10$ & $7,9,10$ & $3,5,7$ & $1,3,5$ & $5,7,9$ \\
\hline & $\mathrm{A}_{2}$ & $7,9,10$ & $1,3,5$ & $5,7,9$ & $1,3,5$ & $1,3,5$ & $5,7,9$ & $7,9,10$ & $1,3,5$ & $1,3,5$ & $3,5,7$ \\
\hline & $\mathrm{A}_{3}$ & $7,9,10$ & $5,7,9$ & $5,7,9$ & $9,10,10$ & $1,3,5$ & $7,9,10$ & $9,10,10$ & $1,3,5$ & $3,5,7$ & $3,5,7$ \\
\hline & $\mathbf{A}_{4}$ & $0,1,3$ & $7,9,10$ & $0,0,1$ & $0,0,1$ & $0,1,3$ & $7,9,10$ & $0,1,3$ & $7,9,10$ & $5,7,9$ & $3,5,7$ \\
\hline & $\mathrm{A}_{5}$ & $3,5,7$ & $5,7,9$ & $1,3,5$ & $5,7,9$ & $1,3,5$ & $3,5,7$ & $1,3,5$ & $3,5,7$ & $5,7,9$ & $3,5,7$ \\
\hline \multirow{2}{*}{ 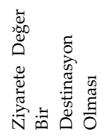 } & $\mathrm{A}_{1}$ & $7,9,10$ & $9,10,10$ & $9,10,10$ & $7,9,10$ & $5,7,9$ & $7,9,10$ & $9,10,10$ & $9,10,10$ & $1,3,5$ & $9,10,10$ \\
\hline & $\mathbf{A}_{2}$ & $7,9,10$ & $3,5,7$ & $7,9,10$ & $3,5,7$ & $3,5,7$ & $7,9,10$ & $5,7,9$ & $7,9,10$ & $5,7,9$ & $7,9,10$ \\
\hline
\end{tabular}




\begin{tabular}{|c|c|c|c|c|c|c|c|c|c|c|c|}
\hline & $\mathbf{A}_{3}$ & $5,7,9$ & $7,9,10$ & $7,9,10$ & $9,10,10$ & $7,9,10$ & $9,10,10$ & $9,10,10$ & $5,7,9$ & $3,5,7$ & $9,10,10$ \\
\hline & $\mathbf{A}_{4}$ & $1,3,5$ & $9,10,10$ & $9,10,10$ & $1,3,5$ & $9,10,10$ & $7,9,10$ & $9,10,10$ & $9,10,10$ & $9,10,10$ & $9,10,10$ \\
\hline & $\mathrm{A}_{5}$ & $7,9,10$ & $5,7,9$ & $9,10,10$ & $1,3,5$ & $9,10,10$ & $7,9,10$ & $9,10,10$ & $7,9,10$ & $5,7,9$ & $9,10,10$ \\
\hline \multirow{5}{*}{ 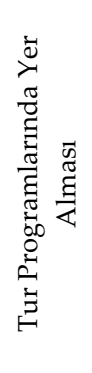 } & $\mathbf{A}_{1}$ & $7,9,10$ & $0,1,3$ & $7,9,10$ & $7,9,10$ & $9,10,10$ & $9,10,10$ & $9,10,10$ & $9,10,10$ & $7,9,10$ & $9,10,10$ \\
\hline & $\mathrm{A}_{2}$ & $7,9,10$ & $5,7,9$ & $3,5,7$ & $7,9,10$ & $5,7,9$ & $9,10,10$ & $9,10,10$ & $5,7,9$ & $7,9,10$ & $7,9,10$ \\
\hline & $\mathbf{A}_{3}$ & $7,9,10$ & $5,7,9$ & $7,9,10$ & $3,5,7$ & $9,10,10$ & $9,10,10$ & $9,10,10$ & $1,3,5$ & $3,5,7$ & $9,10,10$ \\
\hline & $\mathbf{A}_{4}$ & $5,7,9$ & $7,9,10$ & $1,3,5$ & $9,10,10$ & $9,10,10$ & $9,10,10$ & $9,10,10$ & $7,9,10$ & $7,9,10$ & $9,10,10$ \\
\hline & A5 & $7,9,10$ & $7,9,10$ & $1,3,5$ & $7,9,10$ & $9,10,10$ & $9,10,10$ & $9,10,10$ & $9,10,10$ & $5,7,9$ & $9,10,10$ \\
\hline \multirow{5}{*}{ 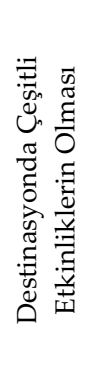 } & $\mathbf{A}_{1}$ & $5,7,9$ & $7,9,10$ & $9,10,10$ & $5,7,9$ & $1,3,5$ & $9,10,10$ & $1,3,5$ & $5,7,9$ & $0,1,3$ & $9,10,10$ \\
\hline & $\mathrm{A}_{2}$ & $7,9,10$ & $1,3,5$ & $7,9,10$ & $3,5,7$ & $5,7,9$ & $9,10,10$ & $7,9,10$ & $3,5,7$ & $0,1,3$ & $7,9,10$ \\
\hline & $\mathrm{A}_{3}$ & $5,7,9$ & $7,9,10$ & $3,5,7$ & $9,10,10$ & $5,7,9$ & $9,10,10$ & $3,5,7$ & $1,3,5$ & $3,5,7$ & $9,10,10$ \\
\hline & $\mathbf{A}_{4}$ & $5,7,9$ & $9,10,10$ & $0,0,1$ & $1,3,5$ & $1,3,5$ & $9,10,10$ & $0,1,3$ & $3,5,7$ & $5,7,9$ & $9,10,10$ \\
\hline & A5 & $5,7,9$ & $7,9,10$ & $0,0,1$ & $5,7,9$ & $7,9,10$ & $9,10,10$ & $1,3,5$ & $7,9,10$ & $5,7,9$ & $9,10,10$ \\
\hline
\end{tabular}

Yapılan dönüşüm sonucunda elde edilen pozitif üçgensel bulanık sayılar, (3) ve (4) numaralı formüller yardımıyla Fuzzy TOPSIS karar matrisine dönüştürülmüştür. Elde edilen matris ve karar kriterlerinin fuzzy ağırlıkları Tablo 7 ve Tablo 8 'de sunulmuştur.

Tablo 7. Fuzzy TOPSIS Karar Matrisi

\begin{tabular}{ccccccccccc}
\hline & $\mathrm{C}_{1}$ & $\mathrm{C}_{2}$ & $\mathrm{C}_{3}$ & $\mathrm{C}_{4}$ & $\mathrm{C}_{5}$ & $\mathrm{C}_{6}$ & $\mathrm{C}_{7}$ & $\mathrm{C}_{8}$ & $\mathrm{C}_{9}$ & $\mathrm{C}_{10}$ \\
\hline & 6.4 & 6.8 & 3 & 4.5 & 6 & 6.6 & 5.8 & 7.2 & 8.9 & 5.1 \\
$\mathbf{A}_{1}$ & 8 & 8.3 & 4.7 & 6.2 & 8 & 8.5 & 7.6 & 8.7 & 8.7 & 6.7 \\
& 9 & 9.1 & 6.5 & 7.7 & 9.4 & 9.7 & 8.8 & 9.4 & 8 & 8 \\
\hline & 5.5 & 5.2 & 3.3 & 4.6 & 4.4 & 5.8 & 3.2 & 5.4 & 6.4 & 4.9 \\
$\mathbf{A}_{2}$ & 7 & 6.9 & 5.1 & 6.4 & 6.4 & 7.5 & 5.2 & 7.4 & 8.2 & 6.7 \\
& 8.1 & 8.2 & 6.9 & 7.9 & 8 & 8.7 & 7 & 8.9 & 9.4 & 8.1 \\
\hline & 7 & 6.4 & 4.8 & 3.8 & 5.8 & 4.4 & 5 & 7 & 6.2 & 5.4 \\
$\mathbf{A}_{3}$ & 8.6 & 8.1 & 6.5 & 5.7 & 7.6 & 6.4 & 6.8 & 8.6 & 7.8 & 7.1 \\
& 9.6 & 9.3 & 7.9 & 7.4 & 8.9 & 8.2 & 8.2 & 9.5 & 8.8 & 8.4 \\
\hline & 8.2 & 2.8 & 3.7 & 3.9 & 2.6 & 2.8 & 2.9 & 7.2 & 7.2 & 4.2 \\
\hline & 9.4 & 4.2 & 5.6 & 5.4 & 3.9 & 4.1 & 4.2 & 8.5 & 8.7 & 5.6 \\
& 9.8 & 5.8 & 7.3 & 6.8 & 5.4 & 5.6 & 5.7 & 9 & 9.4 & 6.9 \\
\hline
\end{tabular}


Tablo 8. Karar Kriterlerinin Fuzzy Ağırlıkları

\begin{tabular}{ccccccccccc}
\hline & $\mathrm{C}_{1}$ & $\mathrm{C}_{2}$ & $\mathrm{C}_{3}$ & $\mathrm{C}_{4}$ & $\mathrm{C}_{5}$ & $\mathrm{C}_{6}$ & $\mathrm{C}_{7}$ & $\mathrm{C}_{8}$ & $\mathrm{C}_{9}$ & $\mathrm{C}_{10}$ \\
\hline \multirow{2}{*}{ Ağırlık } & 0.56 & 0,59 & 0,45 & 0,51 & 0,27 & 0,38 & 0,32 & 0,51 & 0,62 & 0,45 \\
& 0,72 & 0,67 & 0,62 & 0,67 & 0,39 & 0,51 & 0,49 & 0,67 & 0,77 & 0,58 \\
& 0,83 & 0,8 & 0,77 & 0,8 & 0,54 & 0,64 & 0,65 & 0,8 & 0,86 & 0,7 \\
\hline
\end{tabular}

Oluşturulan Fuzzy TOPSIS karar matrisi (5) ve (6) numaralı formüller yardımıyla normalize edilmiştir. Elde edilen yeni matris Tablo 9'da sunulmuştur.

Tablo 9. Normalize Edilmiş Fuzzy TOPSIS Karar Matrisi

\begin{tabular}{|c|c|c|c|c|c|c|c|c|c|c|}
\hline & $\mathrm{C}_{1}$ & $\mathrm{C}_{2}$ & $\mathrm{C}_{3}$ & $\mathrm{C}_{4}$ & $\mathrm{C}_{5}$ & $\mathrm{C}_{6}$ & $\mathrm{C}_{7}$ & $\mathrm{C}_{8}$ & $\mathrm{C}_{9}$ & $C_{10}$ \\
\hline & 0,64 & 0,73 & 0,38 & 0,53 & 0,64 & 0,68 & 0,66 & 0,76 & 0,95 & 0,61 \\
\hline \multirow[t]{3}{*}{$\mathbf{A}_{1}$} & 0,8 & 0,89 & 0,60 & 0,73 & 0,85 & 0,88 & 0,86 & 0,92 & 0,93 & 0,80 \\
\hline & 0,9 & 0,99 & 0,82 & 0,91 & 1 & 1 & 1 & 0,99 & 0,85 & 0,95 \\
\hline & 0,55 & 0,56 & 0,42 & 0,54 & 0,47 & 0,60 & 0,36 & 0,57 & 0,68 & 0,55 \\
\hline \multirow[t]{3}{*}{$\mathrm{A}_{2}$} & 0,7 & 0,74 & 0,65 & 0,75 & 0,68 & 0,77 & 0,59 & 0,78 & 0,87 & 0,80 \\
\hline & 0,81 & 0,88 & 0,87 & 0,93 & 0,85 & 0,90 & 0,80 & 0,94 & 1 & 0,96 \\
\hline & 0,7 & 0,69 & 0,61 & 0,45 & 0,62 & 0,45 & 0,57 & 0,74 & 0,66 & 0,64 \\
\hline \multirow[t]{3}{*}{$\mathbf{A}_{3}$} & 0,86 & 0,87 & 0,82 & 0,67 & 0,81 & 0,66 & 0,77 & 0,91 & 0,83 & 0,85 \\
\hline & 0,96 & 1 & 1 & 0,87 & 0,95 & 0,85 & 0,93 & 1 & 0,94 & 1 \\
\hline & 0,82 & 0,31 & 0,47 & 0,46 & 0,28 & 0,29 & 0,33 & 0,76 & 0,77 & 0,50 \\
\hline \multirow[t]{3}{*}{$\mathbf{A}_{4}$} & 0,94 & 0,45 & 0,71 & 0,64 & 0,41 & 0,42 & 0,48 & 0,90 & 0,93 & 0,67 \\
\hline & 0,98 & 0,62 & 0,92 & 0,80 & 0,57 & 0,58 & 0,65 & 0,95 & 1 & 0,82 \\
\hline & 0,82 & 0,26 & 0,10 & 0,70 & 0,61 & 0,58 & 0,34 & 0,72 & 0,77 & 0,65 \\
\hline \multirow[t]{2}{*}{$\mathrm{A}_{5}$} & 0,96 & 0,41 & 0,28 & 0,87 & 0,79 & 0,76 & 0,57 & 0,88 & 0,93 & 0,85 \\
\hline & 1 & 0,59 & 0,53 & 1 & 0,91 & 0,91 & 0,80 & 0,98 & 1 & 0,99 \\
\hline
\end{tabular}

Normalize hale getirilmiş Fuzzy TOPSIS karar matrisi (7) ve (8) numaralı formüller yardımıyla ağırlıklandırılmıştır. Elde edilen yeni matris Tablo 10'da sunulmuştur.

Sunulan alternatiflerin, Fuzzy pozitif ve Fuzzy negatif ideal çözüm kümesine olan uzaklıkları (9) ve (10) numaralı formüller yardımıyla tespit edilmiştir. Araştırmaya konu olan her bir alternatifin yakınlık katsayısı ise (11) numaralı formül yardımıyla hesaplanmıştır. Elde edilen sonuçlar Tablo 11 'de sunulmuştur. 
Tablo 10. Ağırlıklı Normalize Edilmiş Fuzzy TOPSIS Karar Matrisi

\begin{tabular}{|c|c|c|c|c|c|c|c|c|c|c|}
\hline & $\mathrm{C}_{1}$ & $\mathrm{C}_{2}$ & $\mathrm{C}_{3}$ & $\mathrm{C}_{4}$ & $\mathrm{C}_{5}$ & $\mathrm{C}_{6}$ & $\mathrm{C}_{7}$ & $\mathrm{C}_{8}$ & $\mathrm{C}_{9}$ & $C_{10}$ \\
\hline \multirow{3}{*}{$\mathbf{A}_{1}$} & 0,36 & 0,43 & 0,17 & 0,27 & 0,17 & 0,26 & 0,21 & 0,39 & 0,59 & 0,27 \\
\hline & 0,58 & 0,60 & 0,37 & 0,49 & 0,33 & 0,45 & 0,42 & 0,62 & 0,72 & 0,46 \\
\hline & 0,75 & 0,79 & 0,63 & 0,73 & 0,54 & 0,64 & 0,65 & 0,79 & 0,73 & 0,67 \\
\hline \multirow{3}{*}{$\mathbf{A}_{2}$} & 0,31 & 0,33 & 0,19 & 0,28 & 0,18 & 0,23 & 0,12 & 0,29 & 0,42 & 0,25 \\
\hline & 0,51 & 0,50 & 0,40 & 0,50 & 0,27 & 0,40 & 0,29 & 0,52 & 0,67 & 0,46 \\
\hline & 0,67 & 0,70 & 0,67 & 0,74 & 0,05 & 0,58 & 0,52 & 0,75 & 0,86 & 0,67 \\
\hline \multirow{3}{*}{$\mathrm{A}_{3}$} & 0,39 & 0,41 & 0,28 & 0,23 & 0,17 & 0,17 & 0,18 & 0,38 & 0,41 & 0,29 \\
\hline & 0,62 & 0,58 & 0,51 & 0,45 & 0,31 & 0,34 & 0,38 & 0,61 & 0,64 & 0,49 \\
\hline & 0,80 & 0,80 & 0,77 & 0,70 & 0,51 & 0,54 & 0,60 & 0,80 & 0,81 & 0,70 \\
\hline \multirow{3}{*}{$\mathbf{A}_{4}$} & 0,46 & 0,18 & 0,21 & 0,24 & 0,08 & 0,11 & 0,11 & 0,39 & 0,48 & 0,23 \\
\hline & 0,68 & 0,31 & 0,44 & 0,43 & 0,16 & 0,22 & 0,24 & 0,60 & 0,72 & 0,39 \\
\hline & 0,81 & 0,50 & 0,71 & 0,64 & 0,31 & 0,37 & 0,42 & 0,76 & 0,86 & 0,57 \\
\hline \multirow{3}{*}{ A5 } & 0,46 & 0,15 & 0,05 & 0,36 & 0,17 & 0,22 & 0,11 & 0,37 & 0,48 & 0,29 \\
\hline & 0,69 & 0,28 & 0,17 & 0,58 & 0,39 & 0,39 & 0,28 & 0,59 & 0,72 & 0,49 \\
\hline & 0,83 & 0,47 & 0,41 & 0,80 & 0,49 & 0,58 & 0,52 & 0,78 & 0,86 & 0,69 \\
\hline
\end{tabular}

Tablo 11. Fuzzy Pozitif / Negatif İstenen Çözüme Olan Uzaklıklar ve Yakınlık Katsayısı

\begin{tabular}{lllll}
\hline & $\boldsymbol{d}_{i}^{*}$ & $\boldsymbol{d}_{i}{ }^{*}$ & $\boldsymbol{C} C_{i}$ & Siralama \\
\hline $\mathbf{A}_{\mathbf{1}}$ & 2,82 & 3,96 & 0,5841 & 1 \\
\hline $\mathbf{A}_{\mathbf{2}}$ & 3,39 & 3,27 & 0,4910 & 3 \\
\hline $\mathbf{A}_{3}$ & 2,92 & 3,34 & 0,5335 & 2 \\
\hline $\mathbf{A}_{4}$ & 3,53 & 2,81 & 0,4432 & 5 \\
\hline $\mathbf{A}_{5}$ & 3,35 & 3,09 & 0,4798 & 4 \\
\hline
\end{tabular}

Yapılan araştırma sonucunda, seyahat acentası yetkililerinden oluşan KV grubu, alternatifleri ve sahip olduğu kriterleri değerlendirmiştir. Bu değerlendirmeler sonucunda elde edilen pozitif ve negatif uzaklıklar kullanılarak, her bir alternatifin ideal çözüme olan uzaklığı, yakınlık katsayısı kullanılarak tespit edilmiş̧tir. Buna göre KV grubu; $\mathrm{C}_{1}$ (Doğal çekicilik unsurlarının olması), $\mathrm{C}_{2}$ (Tarihi ve kültürel çekicilik unsurlarının olması), $C_{3}$ (Fiyatların uygun olması), $C_{4}$ (Ulaşım imkanlarının kolaylığı), $C_{5}$ (Konaklama işletmelerinin varlığ $\left.{ }_{1}\right), C_{6}$ (Yiyecek-içecek işletmelerinin varlığı), $C_{7}$ (Diğer turizm işletmelerinin varlığı), $C_{8}$ (Ziyaret etmeye değer bir destinasyon olması), $\mathrm{C}_{9}$ (Seyahat acentalarının tur programlarında yer alması) ve $\mathrm{C}_{10}$ (Destinasyona özgü etkinliklerin 
yapılması) kriterleri barındırma durumlarına göre destinasyon alternatiflerini sıralamıştır. İstenilen çözüme uzaklığı ifade eden Yakınlık Katsayısı'nın 1'e yaklaşması durumunda, alternatifin seçilme şansının arttığı göz önünde bulundurularak sıralama; Safranbolu, Amasra, Akçakoca, Abant ve Yedigöller şeklinde oluşmuştur.

\section{SONUÇ ve DEĞERLENDİRME}

Bir destinasyonun turistik bir ürüne dönüşebilmesi için çekici olması gerekmektedir. Ancak çekicilik tek başına turistik talebin oluşabilmesi için yeterli değildir. Çekicilikle birlikte ulaşılabilirlik, konaklama olanakları, yiyecek içecek, yan ve destek hizmet birimleri, uygun bir fiyat, iyi bir imaj, turistik destinasyona özgü etkinlikler ve turistlerin farklı ihtiyaçlarını karşılayacak onları rahat ettirecek bazı kolaylıkların birbirini desteklemesi gerekmektedir. Turistlerin ilgileri, bir destinasyondan beklentileri ve destinasyonun sahip olduğu turistik ürün yelpazesindeki unsurlar turistlerin karar ve tercihlerini etkilemektedir.

Batı Karadeniz, sahip olduğu doğal güzellikleri, tarihi ve kültürel zenginlikleri ile Türkiye turizmi için önemli bir bölgedir. Son yıllarda tur operatörlerinin ve seyahat acentalarının organize ettikleri günübirlik turlar ve paket turlar incelendiğinde Batı Karadeniz Bölgesi'nde en çok ziyaret edilen ve programlarda sıklıkla yer verilen destinasyonlar olarak Safranbolu, Amasra, Akçakoca, Yedigöller ve Abant ön plana çıkmaktadır. Bu nedenle araştırmada bu beş destinasyona yer verilmiştir. Bir destinasyonda bulunan 10 kriter temel alındığında Batı Karadeniz Bölgesi'nde yer alan 5 turizm destinasyonunun Fuzzy TOPSiS yöntemi ile önem derecelerine göre sıralaması Safranbolu, Amasra, Akçakoca, Abant ve Yedigöller şeklinde oluşmuştur. 1994 yılında UNESCO Dünya Miras Listesi'ne dahil edilen ve 2019 yılında 318.866 ziyaretçiyi ağırlayan (https://safranboluturizmdanismaburosu.ktb.gov.tr) Safranbolu, Batı Karadeniz Bölgesi'nin kültür başkenti olarak bilinmektedir. Hem tarihi ve kültürel zenginliğe hem de doğal güzelliklere sahip olan Safranbolu, sahip olduğu konaklama, yiyecek-içecek ve diğer turizm tesisleri ile uzun yıllardır yerli ve yabancı turistleri ağırlamaktadır. Bartın il sınırları içerisinde yer alan Amasra, denizi, doğası ve tarihi ile turistleri cezbeden destinasyonlardan birisidir. Mesafelerinin yakın olması sebebiyle seyahat acentalarının düzenledikleri turların çoğunluğunda Amasra ve Safranbolu destinasyonları birlikte yer almaktadır. Düzce il sınırları içerisinde yer alan Akçakoca da doğal güzellikleri ve tarihi zenginlikleriyle bilinen önemli bir sahil destinasyonudur. Akçakoca, tur programlarında diğer destinasyonlara kıyasla daha az yer almakla birlikte araştırma kapsamında önem derecesine göre sıralamada üçüncü sıradadır. Bolu il sinırları içerisinde bulunan Abant ve Yedigöller doğal güzellikleriyle bilinen, tur programlarında yer almasının yanı sıra Ankara ve İstanbul gibi büyükşehirlere yakın olması nedeniyle hafta sonları çok sayıda ziyaretçiyi ağırlayan destinasyonlardır.

Araştırmada elde edilen bulgulardan hareketle kamu kurumlarına, yerel yönetimlere, turizm işletmelerine ve turizm paydaşlarına bazı öneriler getirilebilir. Doğal çekiciliklerin olması kriteri incelendiğinde Akçakoca'nın sahip olduğu doğal güzellikleri yeterince ön plana çıaramadığ anlaşılmaktadır. Akçakoca'da, kanyonlar, şelaleler, mağaralar gibi doğal güzelliklere ağırlık veren, kıyı kenti olmanın avantajını kullanarak mavi ile yeşili birleştiren tanıtım ve pazarlama çalışmaları gerçekleştirilmelidir.

Fiyatların uygun olması kriterine verilen yanıtlara göre Abant ve Yedigöller'de uygulanan fiyatların yüksek olarak algılandığı görülmektedir. Turizm işletmelerinin fiyatlarını ve fiyatlandırma politikalarını tekrar gözden geçirmeleri makul bir fiyatlandırma yapmaları destinasyonların rekabet gücünü artırabilir.

Ulaşım imkanlarının kolaylığı, konaklama, yiyecek-içecek ve diğer turizm işletmelerinin varlığı 
kriterlerine verilen yanıtlara bakıldığında Yedigöller destinasyonun birtakım gelişmelere ihtiyaç duyduğu görülmektedir. Öncelikle turistik destinasyonlara ulaşılabilirliğin sağlanması için yol genişletme ve asfaltlama çalışmalarına ağırlık verilmesi gerekmektedir. Bu konuda Karayolları Bölge Müdürlüklerinin, belediyelerin ve turizm paydaşlarının iş birliği içinde çalışması ve Yedigöller'e ulaşım da kullanılan iki farklı yolda düzenleme ve asfaltlama çalışmalarının yapılması gerektiği ifade edilebilir.

Yedi Göller ve Abant'ta konaklama ve yeme-içme tesislerinin kapasitelerinin artırılması ve yeni tesislerin açılması önerilebilir. Özellikle Yedigöller'de konaklama tesisi olarak sadece bir bungalow işletmesinin olması ziyaretçilerin taleplerini karşılama noktasında yetersiz kalabilmektedir. Bu noktada hazırlıksız gelen ve konaklamak isteyen ziyaretçiler için doğal ortamın konseptine uygun olması nedeniyle çadır kiralaması gerçekleştirilebilir. Yine Yedigöller Milli Park alanında bir tane yiyecek içecek işletmesinin olması da talebi karşılama noktasında yetersiz kalmaktadır. Milli parkın doğasını bozmayacak şekilde belirli sayıda yiyecek içecek işletmesinin ve ziyaretçilerin ihtiyaçlarını temin edebilecekleri büfelerin açılması destinasyonun hizmet kalitesine katkıda bulunacaktır. Ayrıca karavan turizmine hizmet edecek yeni alanların tahsis edilmesi ve düzenlenmesi de bölge turizminin rekabet gücünü arttırabilecektir.

Safranbolu; safran festivali, film festivali gibi etkinliklerle de ön plana çıkmaktadır. Batı Karadeniz'deki diğer destinasyonların da etkinliklere önem vermeleri gerekmektedir. Yedigöller ve Abant'ta doğa ve kış turizmine yönelik, Amasra ve Akçakoca'da yaz eğlencelerine, deniz turizmine ve su sporlarına yönelik etkinliklerin düzenlemesi bu destinasyonların çekiciliğine katkıda bulunacaktır.

Batı Karadeniz'deki 5 destinasyon araştırma kapsamında ele alınmıştır. Bundan sonra yapılacak araştırmalara Gölcük de dâhil edilebilir. Ayrıca turistlerin ve turizm paydaşlarının gözüyle de Batı Karadeniz Bölgesi'ndeki destinasyonların sahip olduğu kriterlerin önem derecesi ve sıralaması Fuzzy TOPSİS, VIKOR veya MOORA gibi çoklu kriter teknikleri ile tespit edilerek kıyaslamalar yapılabilir ve çözüm önerileri getirilebilir.

\section{KAYNAKÇA}

Ageeva, E. and Foroudi, P. (2019). Tourists' Destination Image Through Regional Tourism: from Supply and Demand Sides Perspectives, Journal of Business Research, 101, 334-348.

Anand, M. C. and Bharatraj, J. (2017). Theory of Triangular Fuzzy Number, National Conference of Teachers of Mathematics (s. 80-83). Texas: NCATM.

Benur, A. M. and Bramwell, B. (2015). Tourism Product Development and Product Diversification in Destinations, Tourism Management, 50, 213-224.

Bornhorst, T., Ritchie, J.R.B. and Sheehan, L. (2010). Determinant of Tourism Success for MDOs \& Destinations: An Empirical Examination of Stake Holders' Perspectives, Tourism Management, 31, 572-589.

Buhalis, D. D. (2000). Marketing the Competitive Destination of the Future, Tourism Management, 21(1): 97-116.

Chen, C. T. (2000). Extensions of the TOPSIS for Group Decision-Making Under Fuzzy Environment, Fuzzy Sets and Systems, 114, 1-9.

Chen, C., Lin, C. and Huang, S. (2006). A Fuzzy Approach for Supplier Evaluation and Selection in Supply Chain Manager, International Journal of Production Economics, 102(2): 289-301. 
Chen, C-F and Tsai, D.C. (2007). How Destination Image and Evaluative Factors Affect Behavioural Intentions?, Tourism Management, 28, 1115-1122.

Chen, T-Y. and Tsao, C-Y. (2008). The Interval-Valued Fuzzy TOPSIS Method and Experimental Analysis, Fuzzy Sets and Systems, 159(11): 1410-1428.

Chu, T. (2002). Facility Location Selection Using Fuzzy Topsis Under Group Decision, International Journal of Uncertainty, Fuzziness and Knowledge-Based Systems, 10(6): 687-701.

Cracolici, M.F. and Nijkamp, P. (2008). The Attractiveness and Competitiveness of Tourist Destinations: A Study of Southern Italian Regions, Tourism Management, 30: 336-344.

Cucculelli, M. and Goffi, G. (2016). Does Sustainability Enhance Tourism Destination Competitiveness? Evidence from Italian Destinations of Excellence, Journal of Cleaner Production, $111,370-382$.

Ecer, F. (2006). Bulanık Ortamlarda Grup Kararı Vermeye Yardımcı Bir Yöntem: Fuzzy Topsis ve Bir Uygulama, Dokuz Eylül Üniversitesi İşletme Fakültesi Dergisi, 7(2): 77-96.

Echtner, C.M. and Ritchie, J.R.B. (2003). The Meaning and Measurement of Destination Image, The Journal of Tourism Studies, 14(1): 37-48.

Emir, O., Bayer, R. U., Erdoğan, N. K. and Karamaşa, Ç. (2016). Evaluating the Destination Attractions from the Point of Experts' View: An Application in Eskişehir, Turizam, 20(2): 92-104.

Fernández, J.A.S., Azevedo, P.S., Martín, J.M.M. and Martín, J.A.R. (2020). Determinants of Tourism Destination Competitiveness in the Countries Most Visited by International Tourists: Proposal of a Synthetic Index, Tourism Management Perspectives, 33, 1-13.

Gallarza, M. G., Saura, I. G., and García, I. G. (2002). Destination Image: Toward A Conceptual Framework, Annals of Tourism Research, 29(1): 56-78.

Gani, A. N. (2012). A New Operation on Triangular Fuzzy Number for Solving Fuzzy Linear Programming Problem, Applied Mathematical Sciences, 6(11): 525-532.

Getz, D. (2008). Event Tourism: Definition, Evolution and Research, Tourism Management, 29, 403428.

Göksu, A. ve Güngör, İ. (2008). Bulanık Analitik Hiyerarşik Proses ve Üniversite Tercih Sıralamasında Uygulanması, Süleyman Demirel Üniversitesi, İktisadi ve İdari Bilimler Fakültesi Dergisi, 13(3): 1-26.

Güzel, F.Ö. (2010). Turistik Ürün Çeşitlemesi Kapsamında Yeni Bir Dinamik: İnanç Turizmi, Süleyman Demirel Üniversitesi Vizyoner Dergisi, 2(2): 87-100.

Hacıoğlu, N. (2008). Turizm Pazarlaması. (6. Basım), Ankara: Nobel Yayıncilık.

Hashemabadi, A.G. and Razmi, M.J. (2014), Studying Iran`s Tourism Industry Position in Middle East using Tourism Development Indicators and TOPSIS Method, Advances in Management \& Applied Economics, 4(5):85-97.

Hsu, T., Tsai, Y. and Wu, H. (2009). The Preference Analysis for Tourist Choice of Destination: A Case Study of Taiwan, Tourism Management, 30(2): 288-297.

https://safranboluturizmdanismaburosu.ktb.gov.tr/TR-231191/turist-istatistik-verileri.html, [Erişim Tarihi: 20.07.2020].

Huang, J. H. and Peng, K. H. (2012). Fuzzy Rasch Model in TOPSIS: A New Approach for Generating Fuzzy Numbers to Assess the Competitiveness of the Tourism Industries in Asian 
Countries, Tourism Management, 33, 456-465.

İlban M.O. and Yıldırım, H.H. (2017). Determination of Tourism Activities of the World's Best Tourism Destinations Using the Multi-Criteria Decision-Making Method, Cogent Social Sciences, 3(1):1-16.

Islam, S., Hossain, K. and Noor, M.E. (2017). Determining Drivers of Destination Attractiveness: The Case of Nature-Based Tourism of Bangladesh, International Journal of Marketing Studies, 9(3): $10-23$.

İçöz, O. (2013). Turistik Ürün Pazarlamasında İmajın Rolü ve Bölgesel Marka İmajı Yaratma, Yayınlanmamış Doktora Tezi, Dokuz Eylül Üniversitesi, İzmir.

Kim, J. H. (2014). The Antecedents of Memorable Tourism Experiences: The Development of a Scale to Measure the Destination Attributes Associated with Memorable Experiences, Tourism Management, 44, 34-45.

Kılıç, S. (2013). Örnekleme Yöntemleri, Journal of Mood Disorders, 3(1): 44-46.

Kızılırmak, İ. (2006). Türkiye'de Düzenlenen Yerel Etkinliklerin Turistik Çekicilik Olarak Kullanılmasına Yönelik Bir İnceleme, Manas Üniversitesi Sosyal Bilimler Dergisi, 8(15): 181-196.

Klenosky, D.B. (2002). The Pull of Tourism Destinastions: A Means-End Investigation, Journal of Travel Research, 40: 385-395.

Kozak, N., Kozak, M.A. ve Kozak, M. (2012). Genel Turizm Ilkeler ve Kavramlar. (13. Basım), Ankara: Detay Yayıncllı.

Kozak, N. (2012). Turizm Pazarlaması. (4. Basım), Ankara: Detay Yayıncılık.

Kozak, N. (2019). Turizm Pazarlaması, (8. Basım), Ankara: Detay Yayıncılık.

Kurtulay, Z. ve Kızılırmak, İ. (2017). Online Rezervasyon Kanallarında Dijital İmaj ve Fuzzy Topsis Yöntemi ile Değerlendirilmesi, Journal of Recreation and Tourism Research, 4(Special Issue 1): 241-254.

Lee, C. F., Huang, H. I. and Yeh, H. R. (2010). Developing an Evaluation Model for Destination Attractiveness: Sustainable Forest Recreation Tourism in Taiwan. Journal of Sustainable Tourism, 18(6): 811-828.

Mainolfi, G. and Marino, V. (2020). Destination Beliefs, Event Satisfaction and Post-Visit Product Receptivity in Event Marketing. Results from a Tourism Experience, Journal of Business Research, $116,699-710$.

Meydan Uygur, S. (2017). Örnek Olaylarla Turizm Pazarlaması. (1.Basım), Ankara: Detay Yayıncılık.

Moosivand, J. and Farahani, B.M. (2013). Analysing the Relationship Between Urban Infrastructure and Attracting Urban Tourists by Using TOPSIS and AHP Models, Tourism Planning \& Development, 10(4): 467-479.

Murrphy, P., Prichard, M.P. and Smith, B. (2000). The Destination Product and Its Impact on Travel Perceptions. Tourism Management, 21, 43-52.

Olalı, H. ve Timur, A. (1988). Turizm Ekonomisi. İzmir: Ofis Ticaret Matbaacılık Şti.

Olalı, H. (1990). Turizm Politikası ve Planlaması. İstanbul: Yön Ajans.

Önder, E., Yıldırım, B.F. and Özdemir, M. (2013), Multi Criteria Decision Making Approach for Evaluating Tourism Destinations in Turkey, Akademik Turizm ve Yönetim Araştırmaları Dergisi, 1, $1-15$. 
Page, S. and Ge, Y. (2009). Transportation and Tourism: A symbiotic Relationship?, (Editörler) Jamal, T. and Robinson, M.: The Sage Handbook of Tourism Studies içinde (ss. 371-395), London: Sage Publications

Reinius, S.W. and Fredman, P. (2007). Protection Areas as Attractions, Annals of Tourism Research, 34(4): 839-854.

Rızaoğlu, B. (2004). Turizm Pazarlaması. (4. Basım), Ankara: Detay Yayıncılık.

Ritchie, B. and Crouch, G. (2000). The Competitive Destination: A Sustainability Perspective. Tourism Management, 21(2): 1-7.

Rodrigue, J-P. (2020). The Geography of Transport Systems. (Fifth Edition), New York: Routledge.

Sorupia, E. (2005). Rethinking the Role of Transportation in Tourism, Proceedings of the Eastern Asia Society for Transportation Studies, 5, 1767-1777.

Tatar, S., Atak, O. ve Tunaseli, A. (2017). Bir Turistik Çekicilik Örneği: Tiyarto Medresesi, Uluslararası Sosyal Araştırmalar Dergisi, 10(53): 978-985.

Ulucan, E., Kurtulay, Z. ve Kızılırmak, İ. (2018). Sağlık Turizminde Destinasyon Tercih Sıralaması: Fuzzy TOPSIS Yöntemiyle Bir Uygulama, 19. Ulusal Turizm Kongresi Sağllk Turizmi, 17-21 Ekim 2018. Afyonkarahisar.

Uysal, M., Li, X. and Sirakaya Turk, E. (2008). Push-Pull Dynamics in Travel Decisions, (Editörler) Oh, H. and Pizam, A.: Handbook of Hospitality Marketing Management içinde, (ss. 412-439), Abingdon: Routledge.

Wang, Y.-M. and Elhag, T. M. (2006). Fuzzy TOPSIS Method Based on Alpha Level Sets with an Application to Bridge Risk Assessment, Expert Systems with Applications, 31, 309-319.

Vila, M. Costa, G. and Rovira, X. (2010). The Creation and Use of Scorecards in Tourism Planning: A Spanish Example, Tourism Management, 31, 232-239.

Volo, S. (2009). Conceptualizing Experience: A Tourist Based Approach, Journal of Hospitality Marketing \& Management, 18(2-3): 111-126. 